\title{
CHOLERIC CEMETERIES IN THE LANDSCAPE OF THE NORTHERN PART OF THE POLISH JURASSIC HIGHLAND
}

\begin{abstract}
This paper presents the results of ethnographic and archaeological research into potential places of epidemic burial (choleric cemeteries) in two communes in the northern part of the Polish Jurassic Highland, Janów and Mstów. In their descriptions and analysis, ethnographic sources (local memory, accounts provided by inhabitants) and archaeological sources (non-destructive prospecting, probing research) were applied. Apart from presentation of field material, the aim of the paper is to indicate the potential of a combined ethnoarchaeological method applied in research to the contemporary past and to the landscape understood as cultural heritage.
\end{abstract}

Keywords: ethnographic research, archaeological research, ethnoarchaeology, archaeology of the contemporary past, landscape, Polish Jurassic Highland, choleric cemeteries

Received: 23.08.2021 Revised: 01.09.2021 Accepted: 06.09.2021

Citation: Krupa-Ławrynowicz A., Ławrynowicz O. 2021. Choleric Cemeteries in the Landscape of the Northern Part of the Polish Jurassic Highland. "Fasciculi Archaeologiae Historicae" 34, 49-67, DOI 10.23858/FAH34.2021.004

\section{Introduction}

From 2014 to 2019, an interdisciplinary research project on places of memory and places of oblivion present in the local landscape and creating this landscape and its heritage was carried out in five communes in the northern part of the Polish Jurassic Highland. ${ }^{1}$ During ethnographic research, closely referring to the

\footnotetext{
* Institute of Ethnology and Culture Anthropology, University of Lodz; (D https://orcid.org/0000-0003-3532-9677; aleksandra. lawrynowicz@uni.lodz.pl

${ }^{* *}$ Institute of Archaeology, University of Lodz; (D https://orcid.org/0000-0003-3663-9183; olgierd.lawrynowicz@uni.lodz.pl

${ }^{1}$ The research was carried out in five communes of the Częstochowa District: Janów, Lelów, Mstów, Olsztyn, and Przyrów as part of a research project of the National Programme for the Development of Humanities run by the Ministry of Science and Higher Education Miejsca pamięci zapomnienia. Badania interdyscyplinarne pótnocnych terenów Jury Krakowsko-Częstochowskiej I Places of Memory and Oblivion. Interdisciplinary Research of the Northern Part of the Polish Jurassic Highland. For more details on the project, research terms, and the methods used, see: Wejland 2016a; Wejland 2016b; Wejland 2016c; Wejland 2019; Lawrynowicz 2016a; Ławrynowicz 2019b; Ławrynowicz 2019c; KrupaŁawrynowicz, Ławrynowicz 2016; Krupa-Ławrynowicz. Ławrynowicz 2019a; Krupa-Ławrynowicz, Ławrynowicz 2019b.
}

assumptions of the archaeology of the contemporary past, ${ }^{2}$ local inhabitants were asked about important places in their everyday nearby landscape, which were also present in the local collective memory. The interviewees frequently mentioned sepulchral places, particularly those lacking direct continuation between the time they were used and the present and everyday practices connected with it. Therefore, the collected stories included mentions of places of burial that no longer served burial purposes, disappeared, were destroyed, or had been liquidated: devastated Jewish cemeteries in Janów, Mstów, Lelów, and Przyrów, a no longer existing war cemetery from the First World War in Mstów, and the cemetery on Castle Hill in Lelów that had not been used for a few decades. It is also worth mentioning marked and unmarked graves from the time of the January Uprising (1863-1864), individual graves of soldiers who fought in the First World War in the Mstów and Olsztyn Communes, as well as individual and collective graves of soldiers and civilians from the Second World War (inhabitants of all the communes mentioned

\footnotetext{
${ }^{2}$ E.g. González-Ruibal 2014; Zalewska 2016; Krupa-Ławrynowicz and Ławrynowicz 2019b; Ławrynowicz 2019b.
} 
by the interlocutors). The oldest graves outside cemeteries in the area in question were collective commemorative sites of the Warsaw pilgrims murdered by the Russian army in 1792 near Krasice (Mstów Commune) and of fallen January insurgents from 1863 in Mełchów (Lelów Commune).

The tragic and relatively recent ('post-remembered' according to Marianne $\mathrm{Hirsch}^{3}$ ) context for the creation of these graves makes them most similar to the choleric cemeteries discussed in this paper. It draws attention to the fact that knowledge of these places does not come from the closest (family) environment but is rather an effect of individual familiarity with the location of places marked with crosses which 'people say' are graves of $19^{\text {th }}$-century cholera victims. Today it is impossible to determine to what extent the fact that registered memories of choleric cemeteries were limited to seven sites in the Janów Commune and two sites in the Mstów Commune was influenced by possible differences in the number of victims of the cholera epidemic, and to what extent this was a result of varying intensity with which memory of them was cultivated. There is no doubt that the memory of tragic events from the past is upheld better if supported by topography, i.e. the presence of places in the field resembling a grave (for example, the mound in Bystrzanowice-Dwór, Janów Commune) or a cemetery (for example, an area surrounded by boulders on a slope of Dobra Góra (Dobra Mountain) near Wancerzów in the Mstów Commune). The archival survey conducted did not reveal any information about the time these structures were created. In most cases, these places are marked on maps from the end of the $19^{\text {th }}$ century and from the period before the Second World War. ${ }^{4}$

\section{Cholera epidemics. The tragic past in memory and imagination}

Epidemics of infectious disease are collectively remembered as catastrophic and ruthless events. The so-called 'miasma' or 'pestilential air' spared no one: it reached large cities, small towns, and villages alike, dramatically shortening the lives of the old and the young, the poor and the rich. It was believed that a way to keep the plague from spreading was to stop the movement of people, create sanitary cordons, and isolate the sick. People gradually realised the need to improve sanitary standards and to disinfect contaminated places. They tried to minimise contact between the

\footnotetext{
${ }^{3}$ Hirsch 1997.

${ }^{4}$ Karpińska 2016, 68-69; Majorek 2016, 77-82; Karpińska et al. 2016, 223-252; Krupa-Ławrynowicz 2019, 60; Ławrynowicz 2019a, 82; Krupa-Ławrynowicz et al. 2019, 149-150, 155-156.
}

healthy and the infected, whether still alive or already dead. This gave rise to the practice of creating separate, special burial sites, the so-called 'epidemic cemeteries'. Such burial grounds were usually established far from settlements, in undeveloped areas. In many cases, they were transdenominational and the people buried there were the victims of raging epidemics of, for example, pox $\left(12^{\text {th }}\right.$ century), leprosy ( $13^{\text {th }}$ century), the plague ( $14^{\text {th }}$ century), syphilis ( $15^{\text {th }}$ century), dysentery ( $16^{\text {th }}$ century), and typhus ( $18^{\text {th }}$ century). In the $19^{\text {th }}$ century, marked by cholera, cemeteries for victims of this disease were established. ${ }^{5}$

The first mentions of a cholera epidemic appeared in 1817. It was first observed in India, from which it spread further. Most probably, it reached Poland in 1830 through Russia. ${ }^{6}$ Jan Kulesza, M.D., who worked in Warsaw at the time, wrote:

Cholera is a unique, characteristic, and specific disease, different from all other diseases known to us, so that once you have seen it, it is impossible to mistake it for any other. Admittedly, in its manifestations it is marked by its own specific symptoms, which should be called choleric. And so diarrhoea, physiognomy, voice, spasms, skin coldness and colour, pulse, and even blood itself are all special in this disease. Any similar phenomenon wherever occurring will be from now on always called choleric. Once cholera manifests itself in epidemic terms, no one can know how far it will go and where it will meet its end since regardless of the season [...] it is equally dangerous and wreaks havoc everywhere: however, it is malicious in heat rather than in freezing weather. You mostly have to persuade simple folk, they have to be convinced that [...] places where the sick are staying should be frequently aired or smoked with vinegar, chlorine, so that the air is refreshed [...]. And it should be recommended and made sure that flats and homesteads are as clean and tidy as possible; that bodies of stagnant water near buildings and between them do not decompose by sunlight but that they are drained; that places where impurities appear are rinsed with water and that these impurities are directed as far from residential buildings as possible. ${ }^{7}$

Cholera stimulated collective phantasms, reviving both archaic and Christian ideas and imaginings, mixing the 'new order' with the 'old' one. As Monika Sznajderman wrote: 'The plague, even if it only afflicts people, in fact shatters the whole cosmic order of the world, turns it inside out, and establishes order contrary to the normal

\footnotetext{
${ }^{5}$ Surówka 2012, 18.

${ }^{6}$ Surówka 2012, 18.

${ }^{7}$ Kulesza 1838, 61, 75, 120-122.
} 
everyday order' ${ }^{8}$ The mythological image of the world inverted by an epidemic can be found in biblical, apocryphal, literary, and folk sources.

In Polish folk images of cholera, the disease frequently lives deep in the ground and there it lingers, which is why it was associated with a dug-up cemetery.

It only goes out to the world when God orders it to, and then it rejoices greatly because it likes to harm particularly people it does not like. It causes wheat smut and destroys potatoes; wearing a dirty sheet like a storm cloud it flies over houses, and whenever it settles on one, everyone inside it dies. ${ }^{9}$

It sometimes appears in the form of a tall, pale, gaunt virgin dressed in white; in that form it could only be stopped by flowing water or crosses with double arms called 'Caravaca Crosses' (often marked with the first letters of prayer formulas). Such crosses were placed at crossroads or on the edges of villages and towns as if they were defensive walls. ${ }^{10}$ However, the plague is usually ubiquitous: 'There is no way to stop cholera and keep it away from the village. It will go everywhere God sends it'. ${ }^{11}$

Epidemics were turning points in history. In Congress Poland, cholera afflicted the population in 18311832, 1837, 1848-1849, 1852, and 1855. In Galicia, epidemics struck in 1831-1832, 1847-1849, 1855, and 1873. ${ }^{12}$ In the German Opole District, not far from the area of research, there were also confirmed epidemics in $1893-1894 .^{13}$

The authorities of Congress Poland introduced official sanitary regulations determining the method and place of burial of people who died of infectious diseases. For example, they ordered the establishment of separate cemeteries (to be closed after the epidemic), determined the depth of burial pits, and forbade the use of these areas for other purposes. ${ }^{14}$

According to the regulations imposed during a cholera epidemic in Congress Poland in 1831, an epidemic cemetery should be located at least 300 ells away from buildings. ${ }^{15}$ In such cemeteries, the "bodies of the dead and burial pits were covered with lime and pits were dug deeper' ${ }^{16}$ Prussian regulations in the Opole District neighbouring the Częstochowa land to the west

\footnotetext{
${ }^{8}$ Sznajderman 2020, 51.

${ }^{9}$ Udziela 1896, 1-2.

${ }^{10}$ Mikołejko 2012, 119.

${ }^{11}$ Udziela 1896, 2.

12 Tomczyk 2015, 102-103.

${ }^{13}$ Czapliński 2012.

${ }^{14}$ Matejak and Pasternak 2010, 18-19.

${ }^{15}$ Goździk 1939, 18.

${ }^{16}$ O środkach zaradczych w epidemii cholery w r. 1852..., 17.
}

also provided for a separate cemetery for cholera victims, isolated from human settlements. 'The dead were to be dragged with blunt iron hooks into coffins or directly into pits that were at least one fathom deep, and then sprinkled with quicklime'. ${ }^{17}$ The burials of epidemic victims were to take place during the night and were carried out by specially trained people. ${ }^{18}$ In some cases, victims of suicide, the unbaptised, heretics, the excommunicated, blasphemers, and other sinners were buried in choleric cemeteries, as they were all people that could not be buried in the consecrated ground of the parish graveyard.

Stanisław Rumszewicz wrote about a choleric cemetery in Zawodzie in Częstochowa in 1916:

[... It] was a sandy plain covered by winds with sand from nearby hills. [...] A few calcareous rocks and flints lie scattered on the sand. Among this sandy sea, a gigantic twelve-ell red pine cross raises its arms towards the sky. On it, made of nail heads, is the year of erecting the cross: 1894. [...] Nothing here resembles a cemetery, even though those dying of cholera in large numbers were buried there for more than seventy years and, as Michat Deska, an old man in his eighties, claims, a few epidemic victims had been buried there even earlier. [...] According to the testimony of old inhabitants of Zawodzie, there were three epidemics of cholera in Częstochowa: 70 years ago, 58 or 60 years ago, and 30 years ago. ${ }^{19}$

Rumszewicz also provides us with a description of funerary customs, data for which he most probably obtained from the oral tradition he was familiar with or even personal observation:

Three, four, or even five people were buried in one grave, or rather pit, as no stone graves were built in the choleric cemetery. The rich would bring the dead on wagons, a result of which was high demand for wagons; they were difficult to come by and they were very expensive, which is why the poorer population hired Jewish carriers in the market square. A frequent sight was a Jewish carrier with three coffins on his cart. Hospital wagons were followed by policemen. Usually, no one wanted to bury cholera victims, so the policemen following the coffin would order the first person they met to bury it. The usual burial depth was three ells, however, if the shovel struck a different coffin, the new one was simply put on top of it. Coffins at the time were very shallow compared with the present ones.

\footnotetext{
${ }^{17}$ Czapliński 2012, 114.

${ }^{18}$ Czapliński 2012, 121.

${ }^{19}$ Rumszewicz 1916, 5-6.
} 
They remained in the dry sandy ground of the cemetery for a long time. Those living near the choleric cemetery would frequently wake up in the morning only to find three or four coffins lying in the cemetery, left there during the night, which they had to bury. In the choleric cemetery in Zawodzie, only Catholics were buried, while Israelites that died of cholera were buried in the Jewish cemetery. As during every cholera epidemic, a few hundred people died in Czestochowa, Kule, and Zawodzie during the three cholera epidemics that struck Czestochowa in the previous century; according to the calculations of local inhabitants, more than a thousand people died. It was falsely believed that the only cure for cholera was vodka. He who drank a lot of vodka was never touched by cholera. And even those who had already contracted it, overcame it by drinking a quart of this curative liquid a day. [...] With time, cemetery crosses rotted, sand covered the graves, and today only the gigantic cross raises its arms to the sky. Soon, a plough will probably dig the soil, removing the last traces of the choleric cemetery. ${ }^{20}$

In rural areas, bodies of cholera victims were usually thrown into a mass grave dug far from homesteads. Franciszek Nowak, an inhabitant of the village of Lutoryż in the Rzeszów District, ${ }^{21}$ said:

I remember them saying that a choleric corpse was even buried with the furniture he had died on; if he had died on a sofa, then with the sofa, if he had died on a bed, then with the bed, and if he had held a book in his hand, then with the book. All these things had already been infected, so what was the point of keeping them? To let the disease spread further? There were no medicines then, there were no doctors. I mean, there was one medicine for this suffering: death. ${ }^{22}$

The bodies in the pit were covered with quicklime and a layer of earth, sometimes forming a small rise. After the epidemic had ended, the burial place was marked by planting one or two trees ("so that there is a mark after memory has faded. So that people know where the plague lies', remarked the same Franciszek Nowak), ${ }^{23}$ usually lindens or birches; in most cases, also a shrine or a cross was erected there. It was a form of thanksgiving for staying alive during the epidemic. As their symbolic meanings and traditions were not

\footnotetext{
${ }^{20}$ Rumszewicz 1916, 4.

${ }^{21}$ We cite this account despite the geographical distance because of the existence of recurring ideas and practices characteristic of the so-called folk culture, confirmed by ethnographic materials.

${ }^{22}$ Surówka 2012, 19.

${ }^{23}$ Surówka 2012, 19.
}

maintained and cultivated by the community, the cemeteries were not visited by the living, and with time the area was ploughed. What remained was a shrine, a cross. ${ }^{24}$

\section{Choleric cemeteries in the landscape of the northern part of the Polish Jurassic Highland}

The universality of epidemics made burials of victims common. Every town, and perhaps even every village in the Polish Jurassic Highland, had to have a place of epidemic burial. Today, their traces may be lonely crosses, such as the ones near the villages of Lusławice, Bystrzanowice-Dwór, and Piasek in the Janów Commune. In the nearby village of Zajączki in the Kłobuck District, where there used to be a choleric cemetery, St Roch's shrine has been preserved, erected during a cholera epidemic in $1848-1852^{25}$ since, like the epidemic of 1831, the 1848-1852 epidemic took a great toll on the Częstochowa region. In September 1873, a correspondent of Kurier Warszawski wrote:

When in 1852 the most terrifying cholera claimed hun-
dreds of victims in Warsaw every day, I lived in the Pan-
ki Commune in the Wielun District. The nearby towns:
Czestochowa, Kłobuck, Krzepice, Praszka, and the vil-
lages of Truskolasy, Jaciska, Podtęże, Piła, Bór-Zapil-
ski and others, made an offering to the ground of chol-
era victims. ${ }^{26}$

In 1855-1856 and later, the death records of the Złoty Potok parish (Janów Commune) listed nearly twice as many deaths as in $1854 .{ }^{27}$ It seems, however, that a particularly epidemic year in the parish was 1899 , when the number of deaths was a few times higher than the normal death rate. Perhaps the crosses and commemorations in the commune, in the villages of Janów, Złoty Potok, Piasek, Lusławice, and Bystrzanowice-Dwór, should be associated with the years 1855-1856 and 1899. Choleric burials near Mstów were most probably connected with the epidemics of the 1870s and 1880s, but this requires archival research.

Combining knowledge acquired through analysis of written sources with knowledge gained from the inhabitants' stories, burdened with personal beliefs, allowed us to identify a few places in the local physical landscape where, more likely than not, victims of the $19^{\text {th }}$-century cholera epidemics were buried. The places indicated by the inhabitants of Janów and Mstów Communes, where choleric cemeteries were supposedly located, were - in

\footnotetext{
${ }^{24}$ Pigoń 1983, 86; Kolbuszewski 1985, 42.

${ }^{25}$ Związek 2004

${ }^{26}$ Kurier Warszawski 1873, 1.

${ }^{27} \mathrm{AACz} 1853-1905, \mathrm{KM} 1410$.
} 


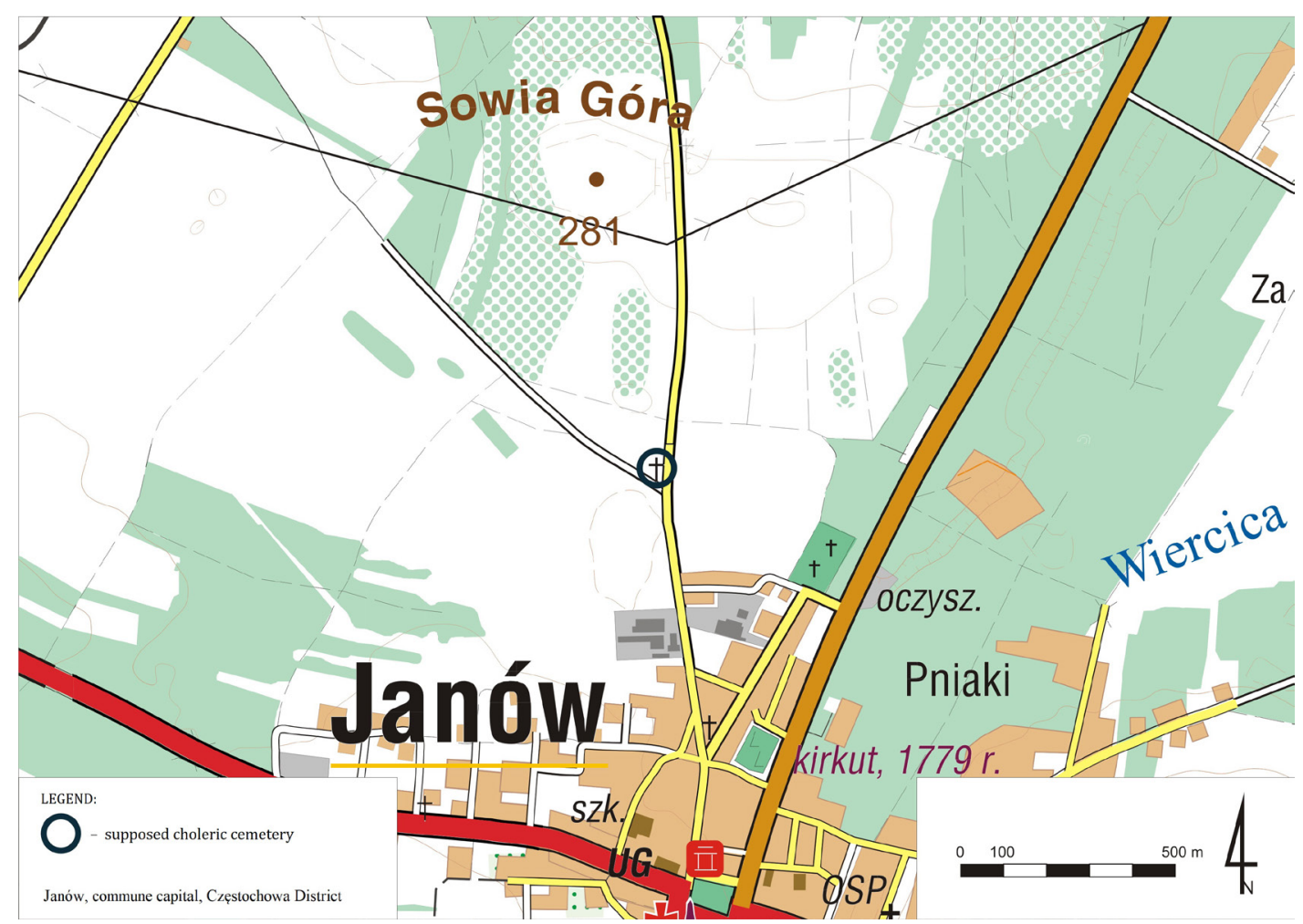

Fig. 1. Location of the supposed choleric cemetery in Janów (commune capital) on a tourist map; prepared by W. Duda based on the map published by Wydawnictwo Kartogram Dariusz Faustmann.

accordance with the assumptions of the research project - assigned to the A category (structures requiring detailed documentation and probing research) and the B category (structures requiring detailed documentation, explored using non-invasive methods). ${ }^{28}$

The A category included structures the research team selected for archaeological verification research - therefore, they had to be places that gave at least reasonable grounds to believe that they once served as choleric cemeteries and that they contained burials of victims of the $19^{\text {th }}$-century epidemics. Two locations marked with crosses in the Janów Commune, in the villages of Janów and Piasek, were selected for probing research.

The supposed choleric cemetery in Janów was thought to be located on the northern edge of the village called Zaborce, at the road to the village of Śmiertny Dąb (Figs. 1-4). ${ }^{29}$ This place, marked with the symbol of a cross, can be seen on a Russian topographic map published in 1912.30

According to the ethnographic interviews conducted with local inhabitants, the cross standing

\footnotetext{
${ }^{28}$ Ławrynowicz 2016a, 95-96.

${ }^{29}$ Karpińska et al. 2016, 225-237.

${ }^{30}$ Novaya Topograficheskaya Karta, sheet XXIX 5 (1912).
} The collection of the Faculty of Geography and Regional Studies of the University of Warsaw; http://igrek.amzp.pl/details. php?id=1762751. Available online: 10.07.2021. there is called by some a choleric cross, while others say it is a welcome sign at which the priest from the Janów church usually waited for a funeral procession coming with a coffin from Śmiertny Dąb. The issue of the choleric cemetery in Janów divides the local community: some would like to see a residential estate built there, others are sceptical to this idea:

As one of the inhabitants said, 'The cemetery is located just outside Janów, there's a cross there at the crossroads. An asphalt road goes into the field, and there's a cross standing there. [...] This is Żurawska road to Śmiertny Dab. [...] When I was seven or eight years old, people dug up or rather ploughed up bones there; they stopped ploughing there, took some part of it, and left it in peace. I guess each town and village here had such a cemetery'. ${ }^{31}$

The archaeological verification research carried out in the place ${ }^{32}$ started with digging a test pit no. 1

${ }^{31}$ All ethnographic research materials - including interview transcripts - can be found in the archive of the project Places of Memory and Oblivion...

${ }^{32}$ The research was carried out based on a permit from the Provincial Office of Monument Preservation in Katowice, Częstochowa branch, on July 5-20, 2016, under the supervision of Dr Olgierd Ławrynowicz by mgr Maja Maruszewska, mgr Damian Lechicki, mgr Łukasz Sierpowski, and a group of archaeology students of the University of Lodz. 


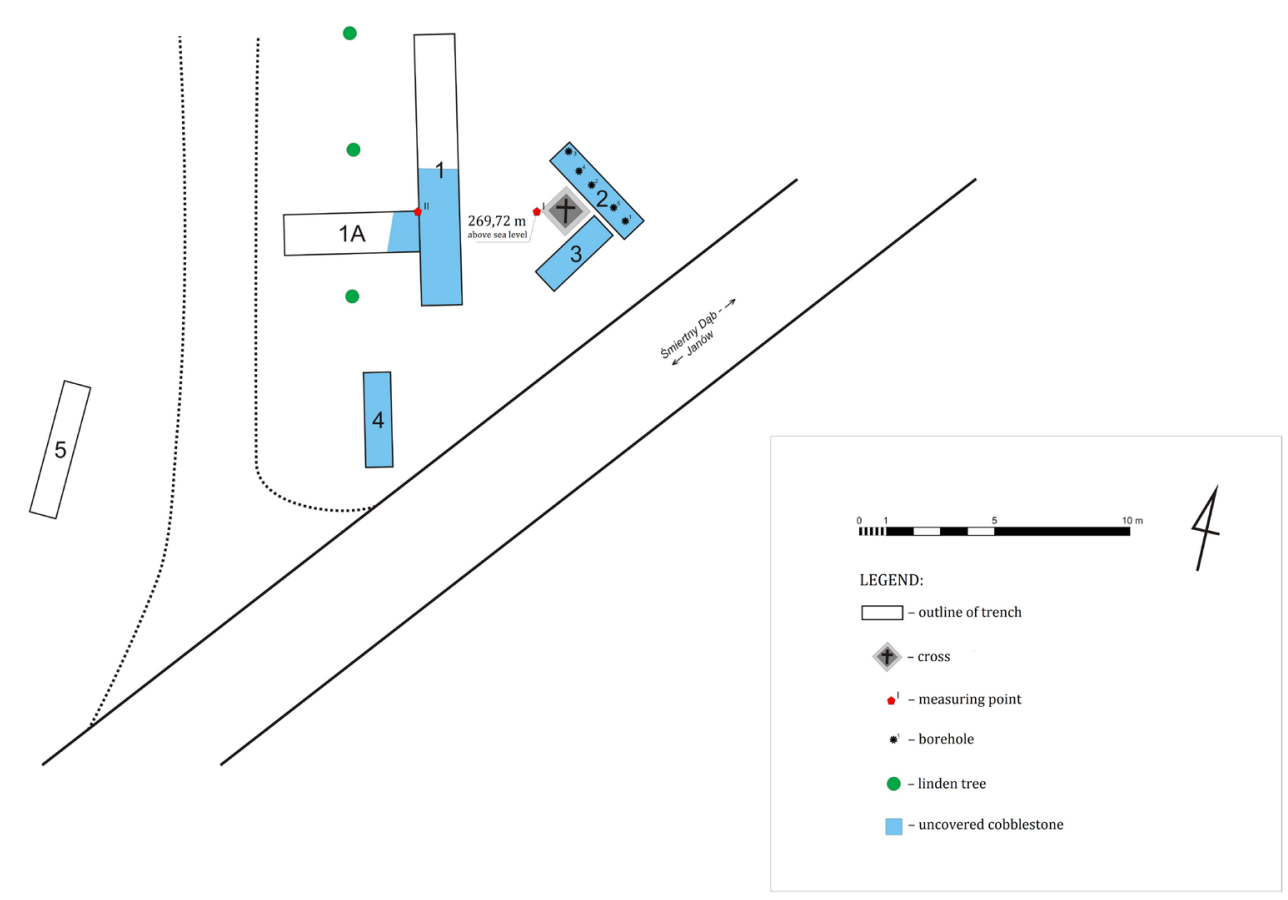

Fig. 2. A site plan of test pits in the supposed choleric cemetery in Janów (commune capital); prepared by W. Duda.

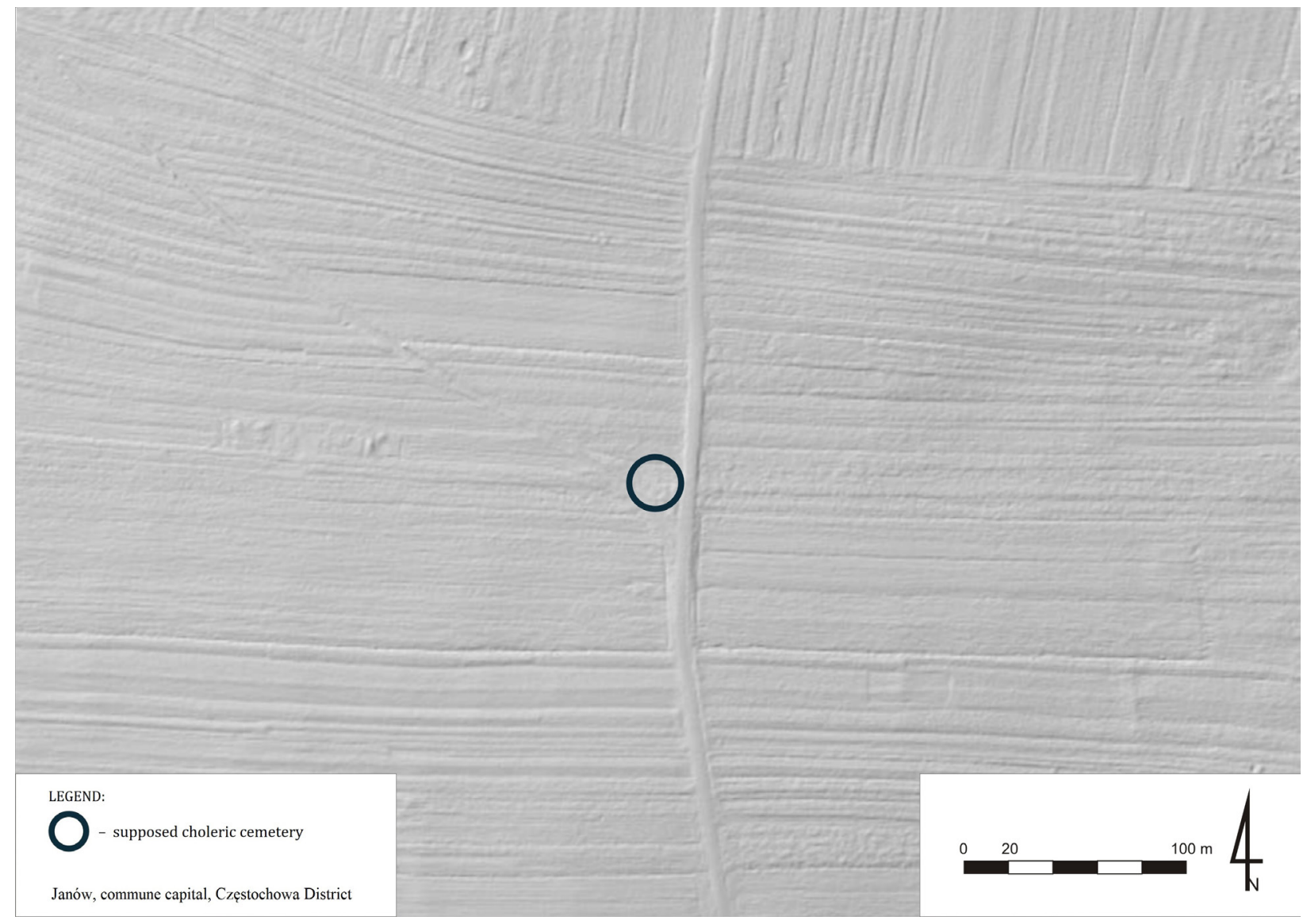

Fig. 3. Location of the supposed choleric cemetery in Janów on a map; prepared by A. Ginter, W. Duda based on the data of the Head Office of Geodesy and Cartography. 


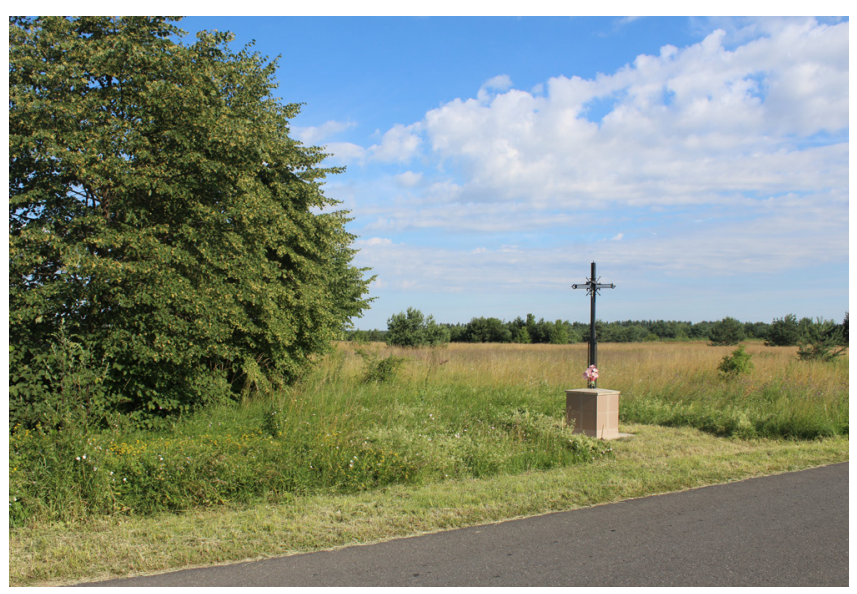

Fig. 4. Janów (commune capital), a general view from the south before the beginning of probing research; photograph by Ł. Sierpowski; July 2016.

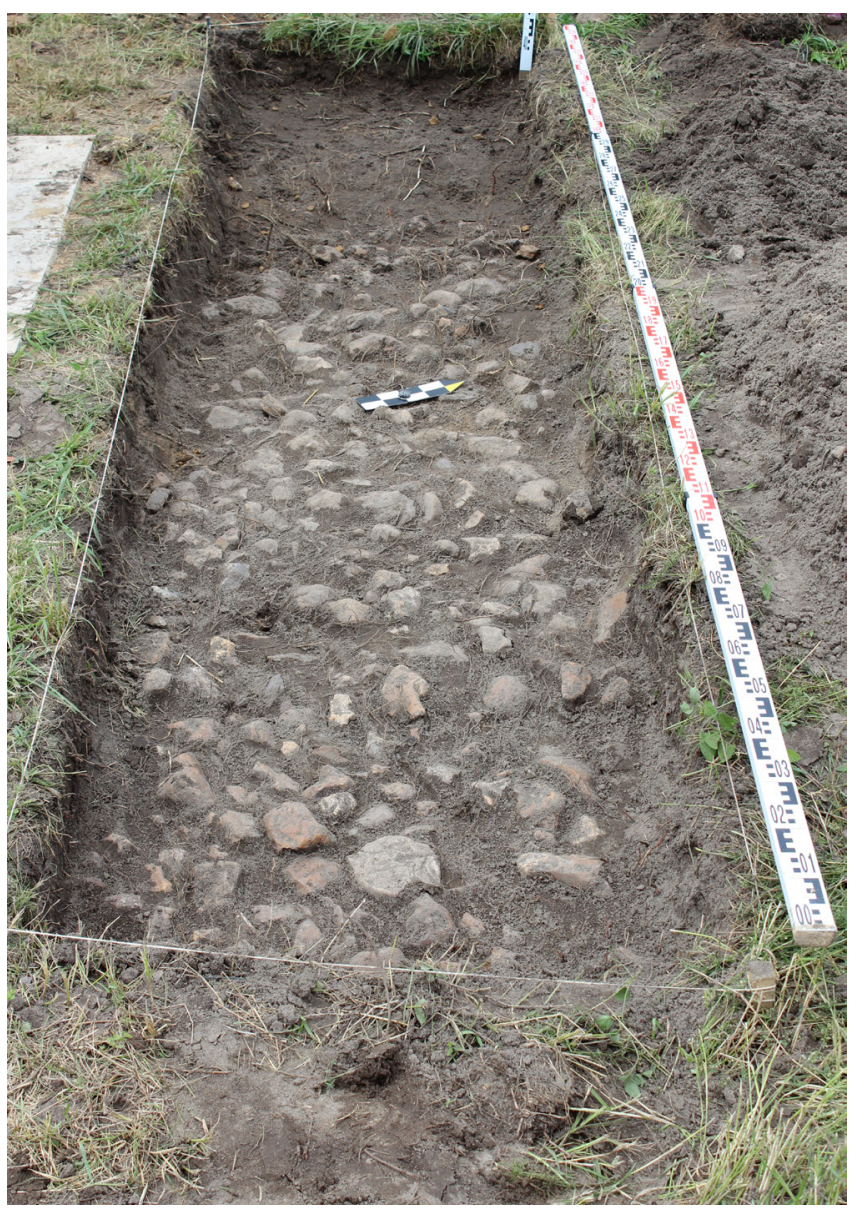

Fig. 5. Janów (commune capital), excavation no. 2. Cobblestones found under the topsoil. A view from the east; photograph by D. Lechicki; July 2016.

near the roadside metal cross. It was oriented along the NW-SE axis, limiting the exploration area to a rectangle measuring $1.5 \times 10 \mathrm{~m}$. Its exploration did not reveal any accumulations that would indicate presence of burials. The only relics of human activity were cobbles found in the southern section of the excavation, which ended in the marked out annex no. $1 \mathrm{~A}$ measuring $1.5 \times 5.0 \mathrm{~m}$, located perpendicularly to the NE-SW axis. Another two surveys, an excavation no. 2 measuring $1 \times 4.0 \mathrm{~m}$ and no. 3 measuring $1 \times 5.0 \mathrm{~m}$, were located right next to the cross (excavation 2 north of the cross and excavation 3 east of the cross). Also in these places a rather regular cobbled surface was unearthed (Fig. 5). In the area explored, no anthropogenic structures were found, except for a garbage pit in excavation no. 2. An analogous sequence of layers - topsoil, cobbles (or lack thereof), yellow sand mixed with humus, and a natural layer of yellow sand, clay, and small calcareous stones (with the ceiling of that layer at a depth of about $50 \mathrm{~cm}$ ) - was discovered in other surveys: in excavation no. 4 , measuring $1 \times 3.5 \mathrm{~m}$, located parallel to excavation no. 1 (south of the metal cross, approx. $1 \mathrm{~m}$ to the west of the road), and in excavation no. 5, located south of the cross on the other side of the road. During the research, twenty-two fragments of dish ceramics and three fragments of glazed tiles from the $19^{\text {th }}$ century or the first half of the $20^{\text {th }}$ century, four fragments of daub, a knife blade and a fragment of a knife blade, a nail (perhaps from a horseshoe), and two animal bones were found. Due to the poor clarity of the sterile earth, longitudinal deepening and boreholes were made using a stirrup drill bit, which excluded the presence of further cultural accumulations. Thus, the discovery that proved to be most interesting was the cobbled surface, probably made of stones that for decades had been thrown away by farmers while ploughing nearby fields. Not so long ago, it could be used as the surface for ceremonies held there. This was the place where the priest from Janów supposedly waited for funeral processions coming with coffins from Śmiertny Dąb. Although archaeological research did not confirm the presence of a choleric cemetery immediately at the cross, it cannot be excluded that the cemetery was located in a different, nearby yet unmarked, place. ${ }^{33}$

Archaeological research in the eastern section of the village of Piasek, on two private plots of land located west of a wooden cross on Kwiatowa Street, was carried out on the initiative of Joanna Ścigaj, head of the Janów Commune, who, having consulted local inhabitants, suggested that a choleric cemetery could have existed there in the past (Figs. 6 and 7). ${ }^{34}$ This place is marked with the symbol of a cross on the same Russian topographic map published in 1912 as the supposed cemetery in Janów. ${ }^{35}$

\footnotetext{
${ }^{33}$ Karpińska et al. 2016, 225-237.

${ }^{34}$ The research was carried out based on a permit from the Provincial Office of Monument Preservation in Katowice, Częstochowa branch, on July 11-19, 2016, under the supervision of Dr Olgierd Ławrynowicz by mgr Magdalena Majorek and a group of archaeology students of the University of Łódz.

${ }^{35}$ Novaya Topograficheskaya Karta, sheet XXIX 5.
} 


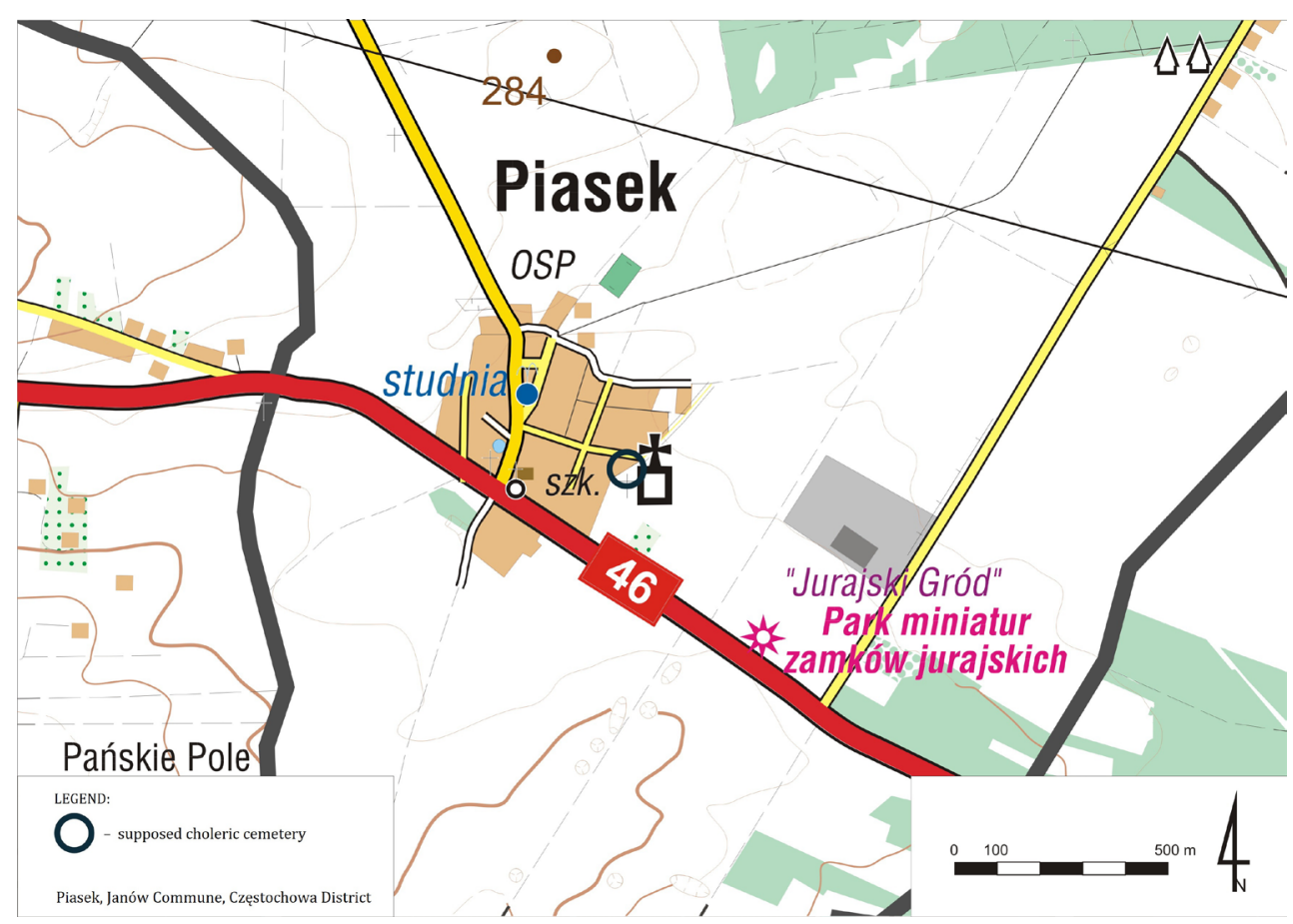

Fig. 6. Location of the supposed choleric cemetery in Piasek (Janów Commune) on a tourist map; prepared by W. Duda based on the map published by Wydawnictwo Kartogram Dariusz Faustmann.

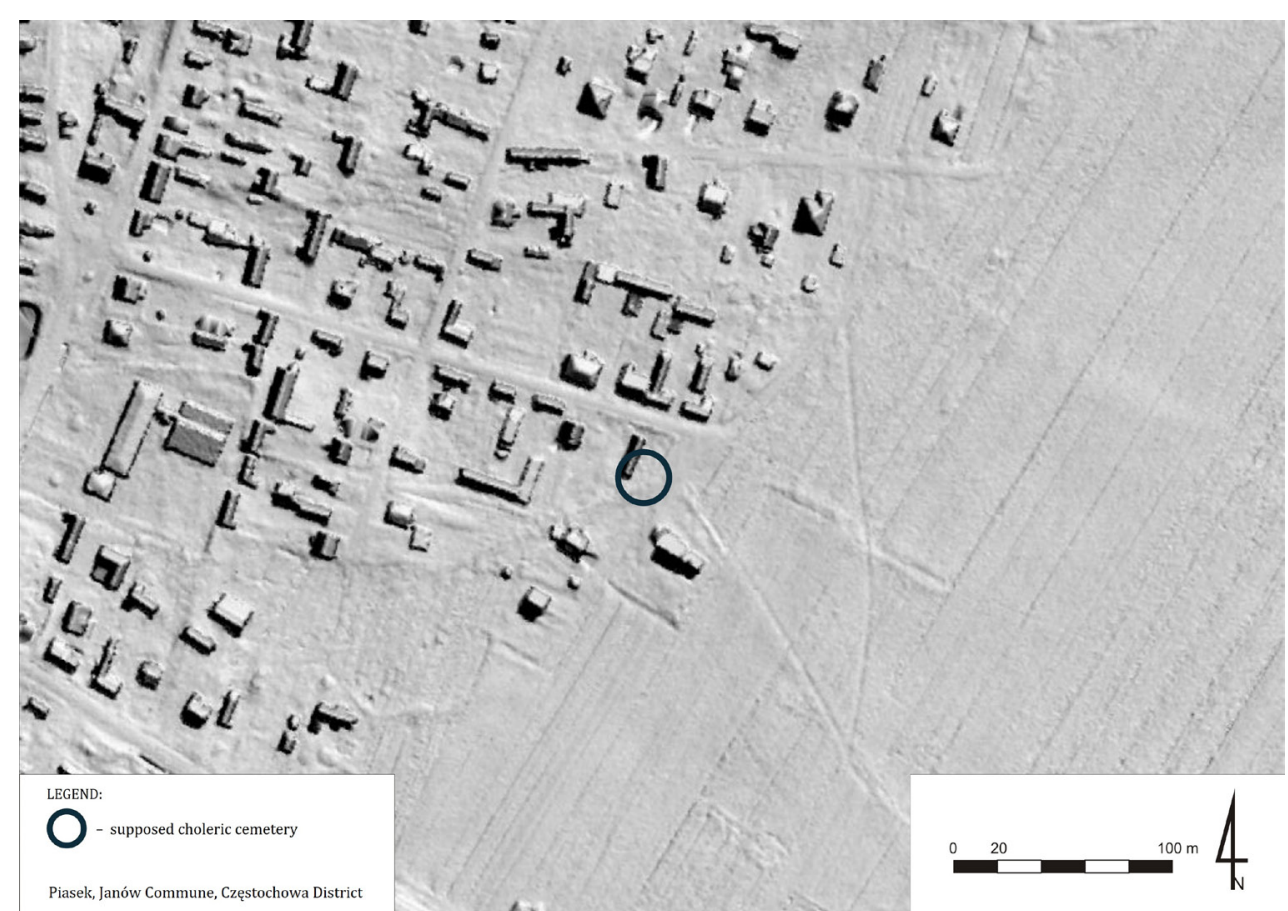

Fig. 7. Location of the supposed choleric cemetery in Piasek (Janów Commune) on a LiDAR visualisation; prepared by A. Ginter, W. Duda based on the data of the Head Office of Geodesy and Cartography. 




Fig. 8. Piasek (Janów Commune), a general view from the south of excavation no. 1 and a wooden cross (to the right at the back) before the beginning of research; photograph by M. Majorek; July 2016.

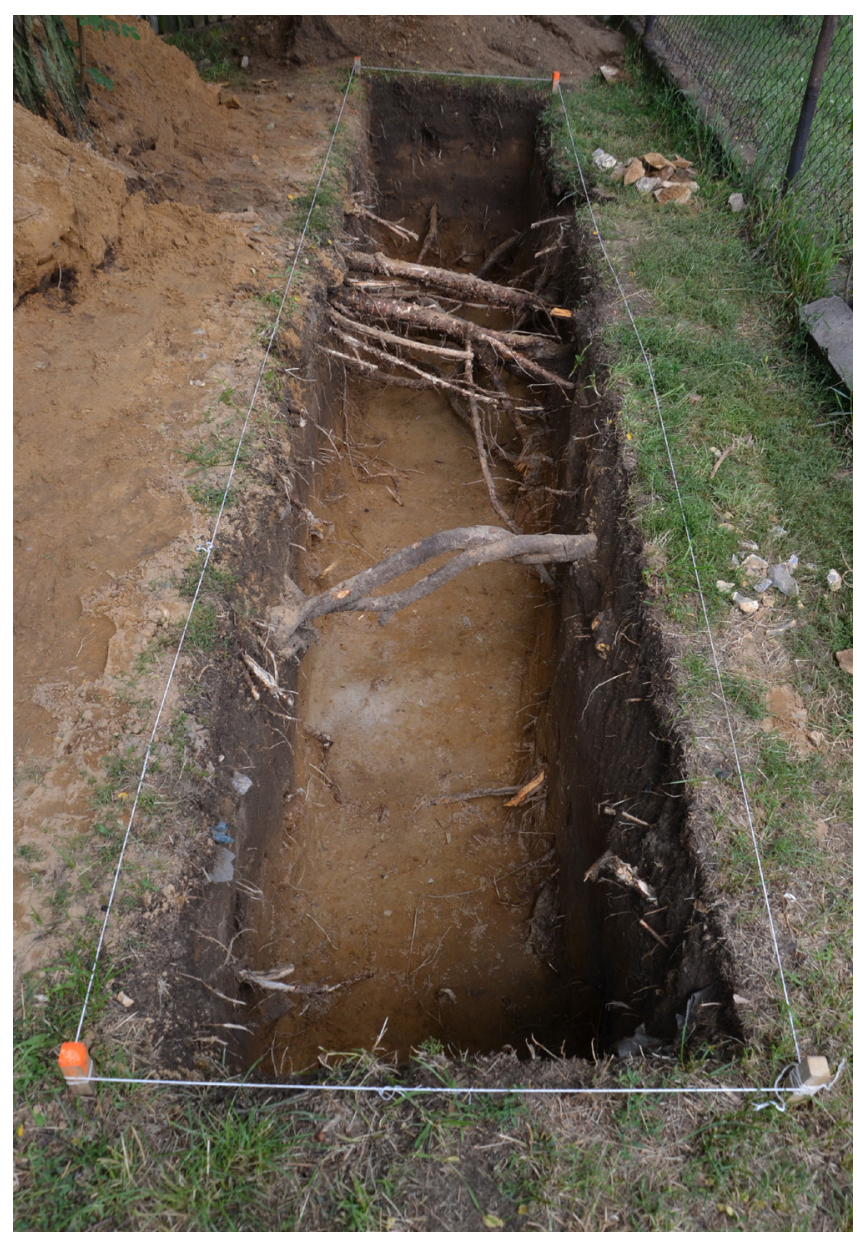

Fig. 9. Piasek (Janów Commune), a general view from the south of excavation no. 1 after the end of exploration; photograph by M. Majorek; July 2016.

The first excavation was dug next to the cross on the southern plot (no. 583), limiting the exploration area to a rectangle measuring $1.0 \times 5.0 \mathrm{~m}$ (Figs. 8 and 9 ) and 11 boreholes were made using a stirrup drill bit south of it. The research there did not reveal any anthropogenic traces. Seven boreholes were also made near the cross on the northern plot (no. 582). When they uncovered a layer of sand mixed with humus, a decision was made to make another excavation measuring $1.0 \times 1.5 \mathrm{~m}$. At the depth of $1.2 \mathrm{~m}$, a water pipe was uncovered, lying directly on sterile earth. No elements of material culture that could be dated to the period before the mid- $20^{\text {th }}$ century were found in the two probing pits. Archaeological research excluded the existence of a cholera cemetery in that exact location in the past; however, it cannot be conclusively stated that a cholera cemetery was not located somewhere near. ${ }^{36}$

As it was already mentioned, other places were classified into the B category, in which archaeological research was limited to non-destructive prospecting. This group included a mound located in the village of Bystrzanowice-Dwór, which was the only place in the Janów Commune marked in the field as a choleric cemetery. However, it is not marked on archival maps. This is what local inhabitants had to say:

Oh, it's between Bystrzanowice-Dwór and Bystrzanowice. There are these crosses. People there suffered from the plague or cholera. They suffered from cholera, and these people were buried there.

When you go from Bystrzanowice to Bystrzanowice-Dwór, after some two kilometres you will see this mound to the left. This is the place where cholera victims were buried. It is a commemorative grave, there were three crosses on it at first, but now there is only one.

The place was located on an anthropogenic mound, east of the intersection of Jesionowa Street and Gorska Street (Figs. 10-12). On top of it, a wooden cross with a figure of crucified Christ was identified. Its crossbar is oriented along the NE-SW axis. The figure of Christ faces the north-west. The cross is surrounded by a wooden fence on a rectangular plan measuring $1.24 \times 1.62 \mathrm{~m}$, which is $0.8 \mathrm{~m}$ high. The structure was decorated with artificial flowers. Approx. $1.5 \mathrm{~m}$ to the south-east, there is a nearly eighty-year-old birch with an image of Our Lady of Częstochowa. The relative height of the mound is 3-4 m. Both the mound and the area around it are overgrown with high grass. The place was marked with a small wooden sign with an inscription: A COLLECTIVE GRAVE FROM THE PERIOD OF THE PESTILENTIAL AIR. ${ }^{37}$

Another supposed location of a choleric cemetery in the Janów Commune is the vicinity of the village of Lusławice. This is what the local inhabitants had to say:

\footnotetext{
${ }^{36}$ Karpińska et al. 2016, 242-245.

${ }^{37}$ In Polish: 'ZBIOROWA MOGIŁA Z OKRESU MOROWEGO POWIETRZA', Karpińska et al. 2016, 250-252.
} 


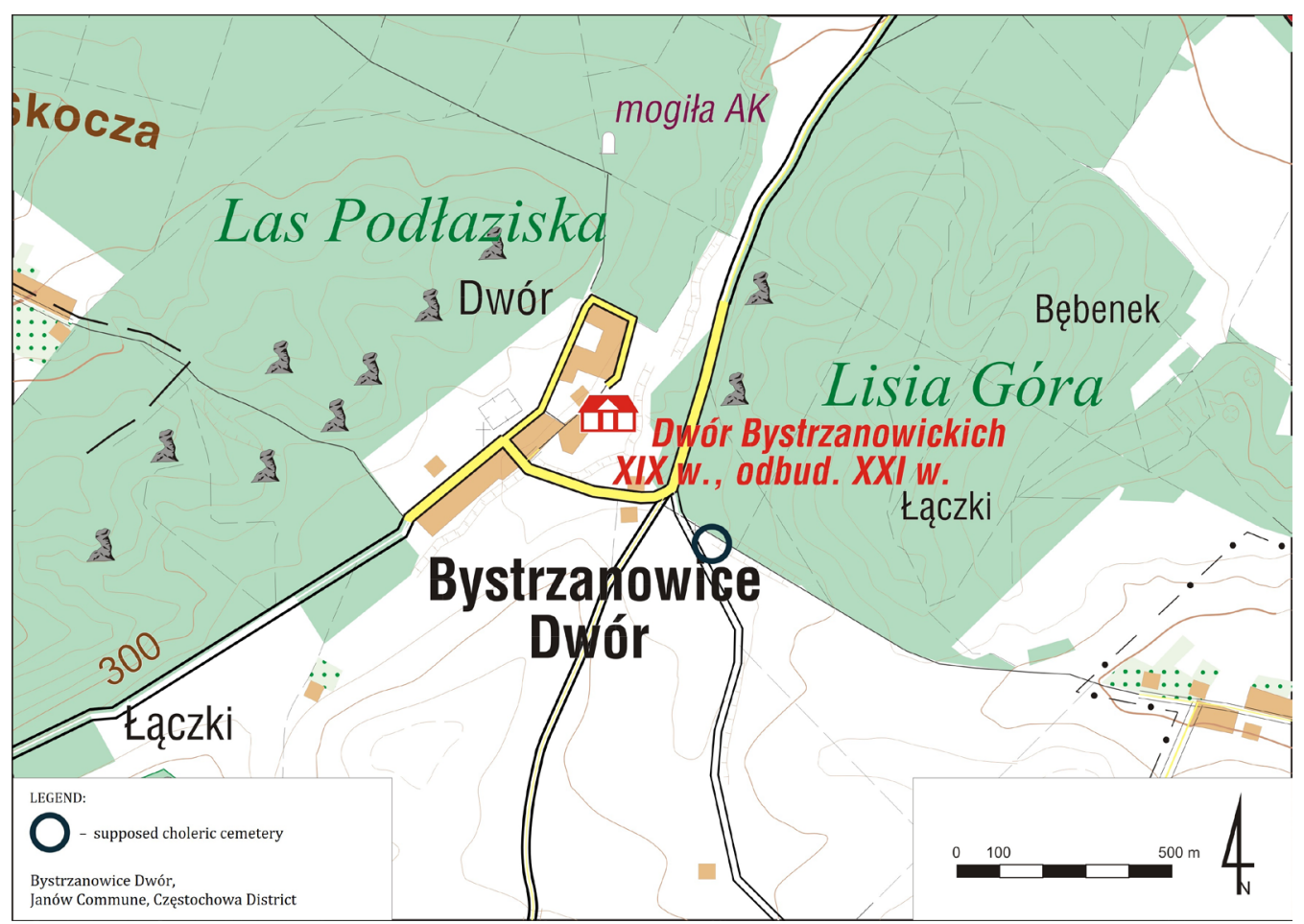

Fig. 10. Location of the supposed choleric cemetery in Bystrzanowice-Dwór (Janów Commune) on a tourist map; prepared by W. Duda based on the map published by Wydawnictwo Kartogram Dariusz Faustmann.

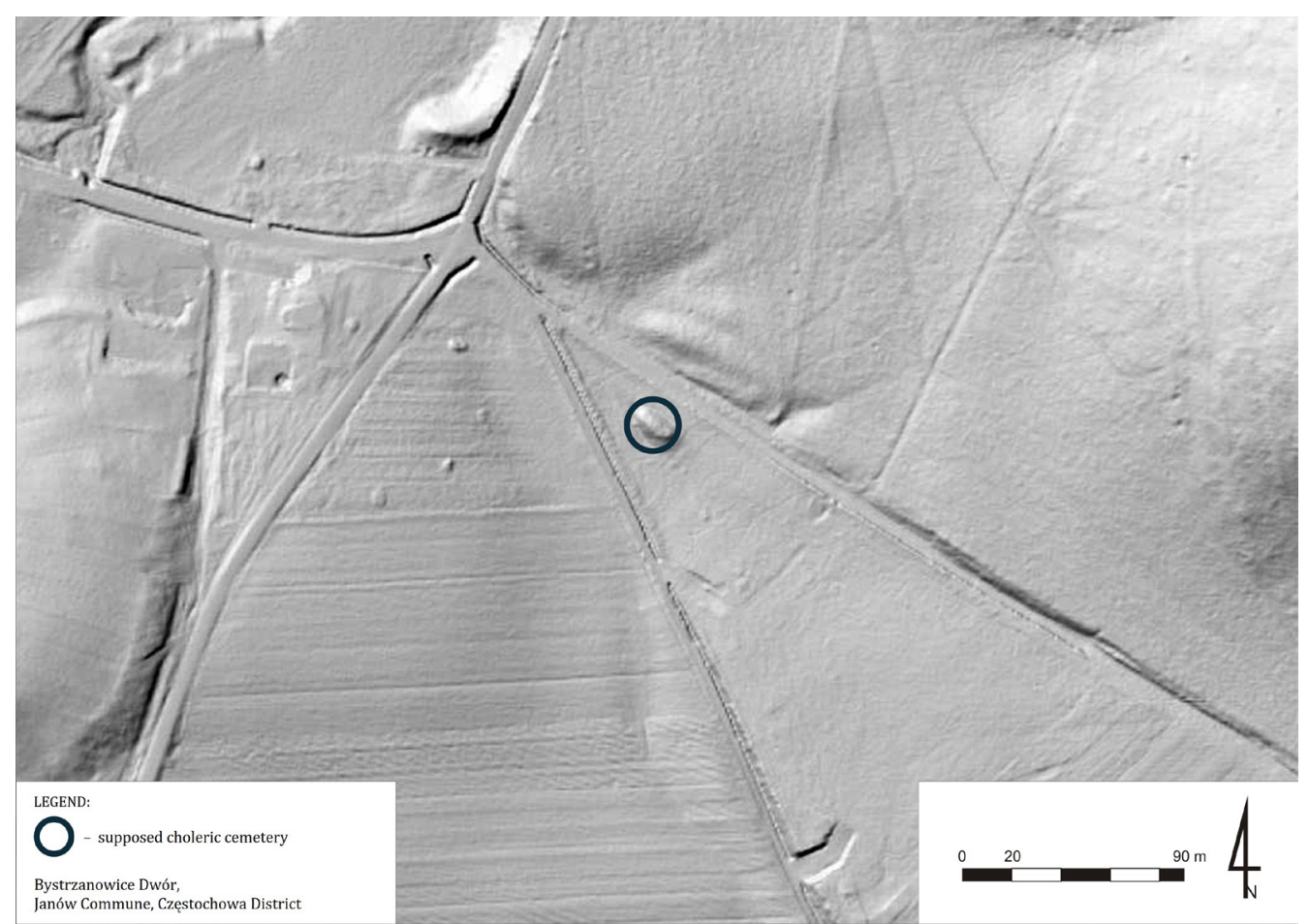

Fig. 11. Location of the supposed choleric cemetery in Bystrzanowice-Dwór (Janów Commune) on a LiDAR visualisation; prepared by A. Ginter, W. Duda based on the data of the Head Office of Geodesy and Cartography. 


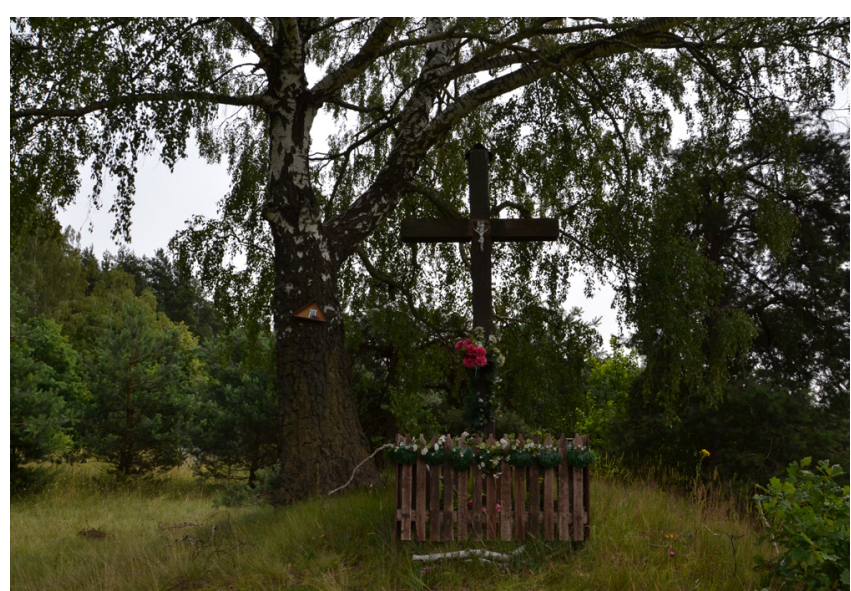

Fig. 12. Bystrzanowice-Dwór, the supposed choleric cemetery, a view from the north; photograph by M. Majorek, July 2016.

Lustawice, where today is the transformer. Cholera victims were most probably buried there back in eighteen something. Those who erected the transformer came across human bones but kept it secret because they were afraid that the authorities would stop the work and the houses would not have electricity. They simply covered them because if they said something, there would be no transformer either here or there, so it was better to keep it secret, and that's that. It's obvious there used to be a cemetery there because there's a cross near the woods, towards Żuraw. And there is a shrine painted red in the woods, and people have long said that it was built to commemorate cholera victims.

The place was located in the eastern part of the village of Lusławice, south of the asphalt road to the village of Okrąglik, on the outside of the curve of a turning traffic route (Figs. 13-15). What particularly drew the researchers' attention was an area covering approx. 10 ares. Thick grass and weeds (mostly nitrophilous nettles), a stream, and a transformer standing approx. $2.5 \mathrm{~m}$ away from the road were documented. The area was potentially available for archaeological research; however, there were no visible signs of a cemetery on the surface. Not far away, a metal cross of welded bars with a figure of the crucified Christ was found, standing on a stone with a plastered plinth, decorated with artificial flowers. ${ }^{38}$

During the ethnographic research carried out in the Janów Commune, fragmentary information about other places where graves of cholera victims were to be located was also obtained. The interviewees - inhabitants of the district - said that 'the old people who knew [about the graves] are already dead, there is no

${ }^{38}$ Karpińska et al. 2016, 246-248. one left'. The places mentioned included the pond near the main square in Lusławice, Wilcza Góra in Złoty Potok, and the cross in the village of Siedlec. ${ }^{39}$

In the Mstów Commune, accounts of choleric cemeteries provided by local inhabitants were connected with two places located on the left (northern) bank of the Warta River: on the south-western slope of Dobra Mountain on the western edge of the village of Wancerzów, and on Gminna Street on the north-eastern edge of Mstów. Both these places are marked as cemeteries on a Polish tactical map of 1933 (Fig. 16)..$^{40}$ Moreover, the cemetery on today's Gminna Street is marked on a German map of the 1880 s. $^{41}$

Today, the place marked as a cemetery for people who died during a cholera epidemic is the area located on a slope of Dobra Mountain (Figs. 17-20). An information board was placed there, which was an element of an undertaking carried out in the Mstów Commune in 2015 under the collective title 'Following the Past in the Mstów Commune (Polish: 'Śladami Przeszłości po Gminie Mstów'). ${ }^{42}$ Boards with photographs and a brief note on the history of each place (which no longer exists or has changed its character) were installed in the original locations of structures connected with the local history and heritage. The originators of the project were commune authorities and its co-authors - which is worth emphasising - were local inhabitants. They not only shared their memories (which served as a basis for the descriptions), but opened their home archives and provided unique photographs, unavailable in so-called 'official' studies. Information on the board and accounts collected during the ethnographic research indicate that this was the location of the graves of people who died of cholera after the January Uprising in $1863 .{ }^{43}$

The area is overgrown with trees and used to be surrounded by a stone wall (the remains of which are still visible in the eastern part). The surface is uneven, and there is a clear linear hollow along the E-W axis. There are no visible remains of the graves. In the south-western part, there is a five-metre-high wooden cross made of round logs painted red. The crossbeam is oriented along the E-W axis, and the figure of Christ faces south. ${ }^{44}$

The cemetery in Gminna Street in Mstów (which until the mid- $20^{\text {th }}$ century was a part of the village of

\footnotetext{
${ }^{39}$ Karpińska 2016, 68-69; Karpińska et al. 2016, 238-241.

${ }^{40}$ Mapa taktyczna... 1933. P45 S28 - Częstochowa.

${ }^{41}$ Karte... 1886, B1. 454 - Herby.

${ }^{42}$ Krupa-Ławrynowicz 2020.

${ }^{43}$ It is worth noting that there is a legend connected to Dobra Mountain, according to which it was the burial place of insurgents hanged by Russian soldiers in the market square in Mstów in 1863; Kubicki 2012, 73.

${ }^{44}$ Krupa-Ławrynowicz et al. 2019, 149-150.
} 


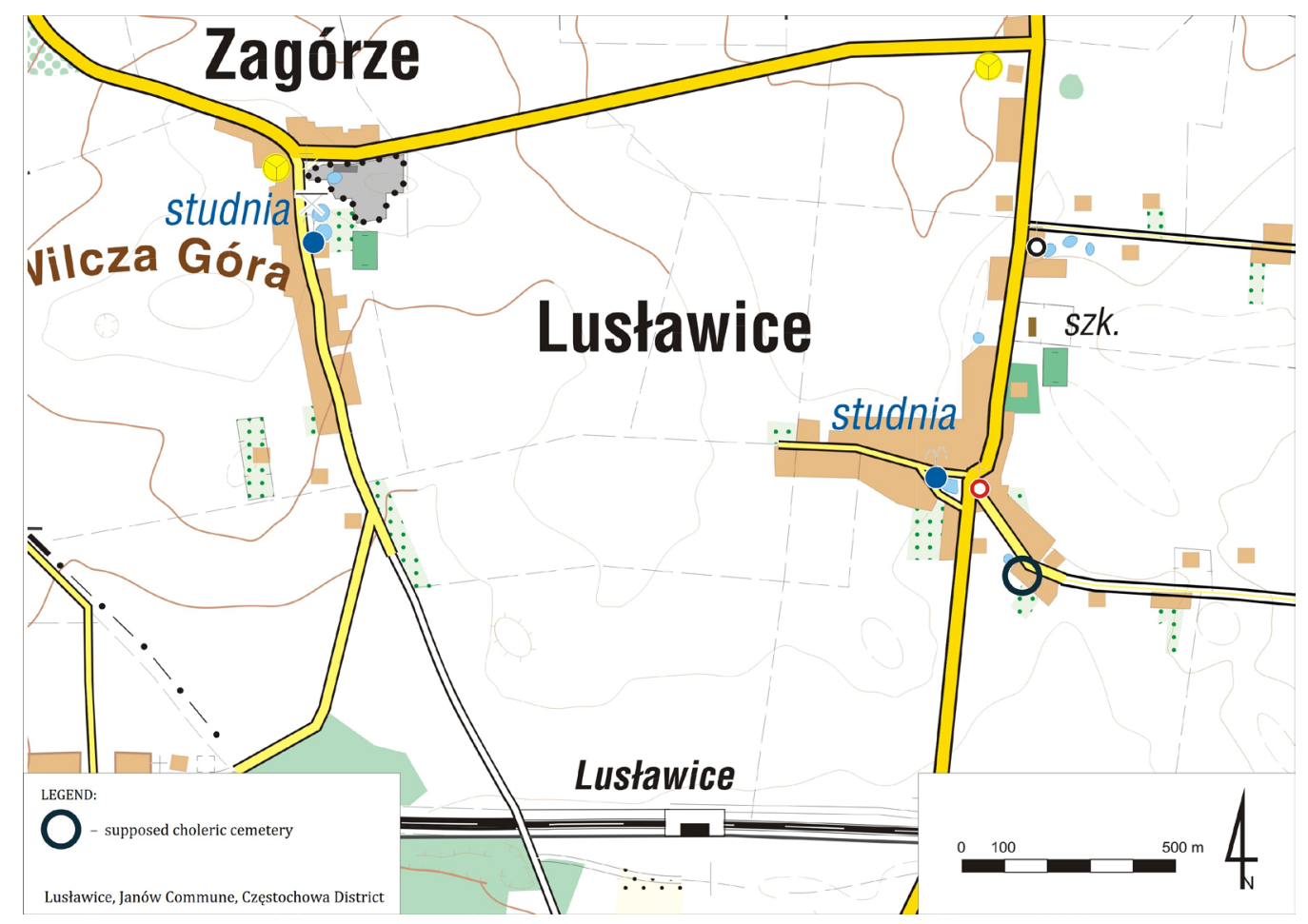

Fig. 13. Location of the supposed choleric cemetery in Lusławice (Janów Commune) on a tourist map; prepared by W. Duda based on the map published by Wydawnictwo Kartogram Dariusz Faustmann.

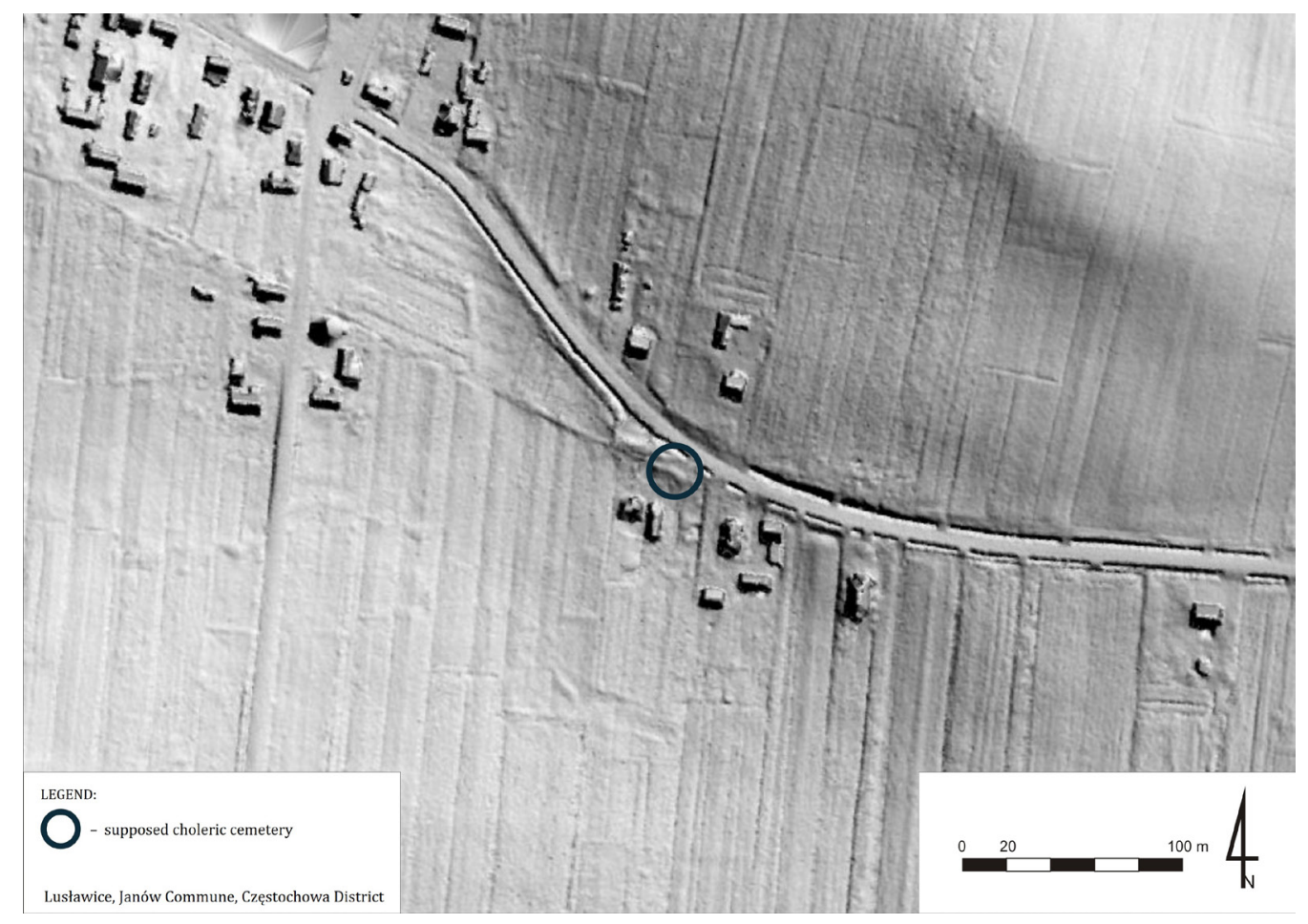

Fig. 14. Location of the supposed choleric cemetery in Lusławice (Janów Commune) on a LiDAR visualisation; prepared by A. Ginter, W. Duda based on the data of the Head Office of Geodesy and Cartography. 


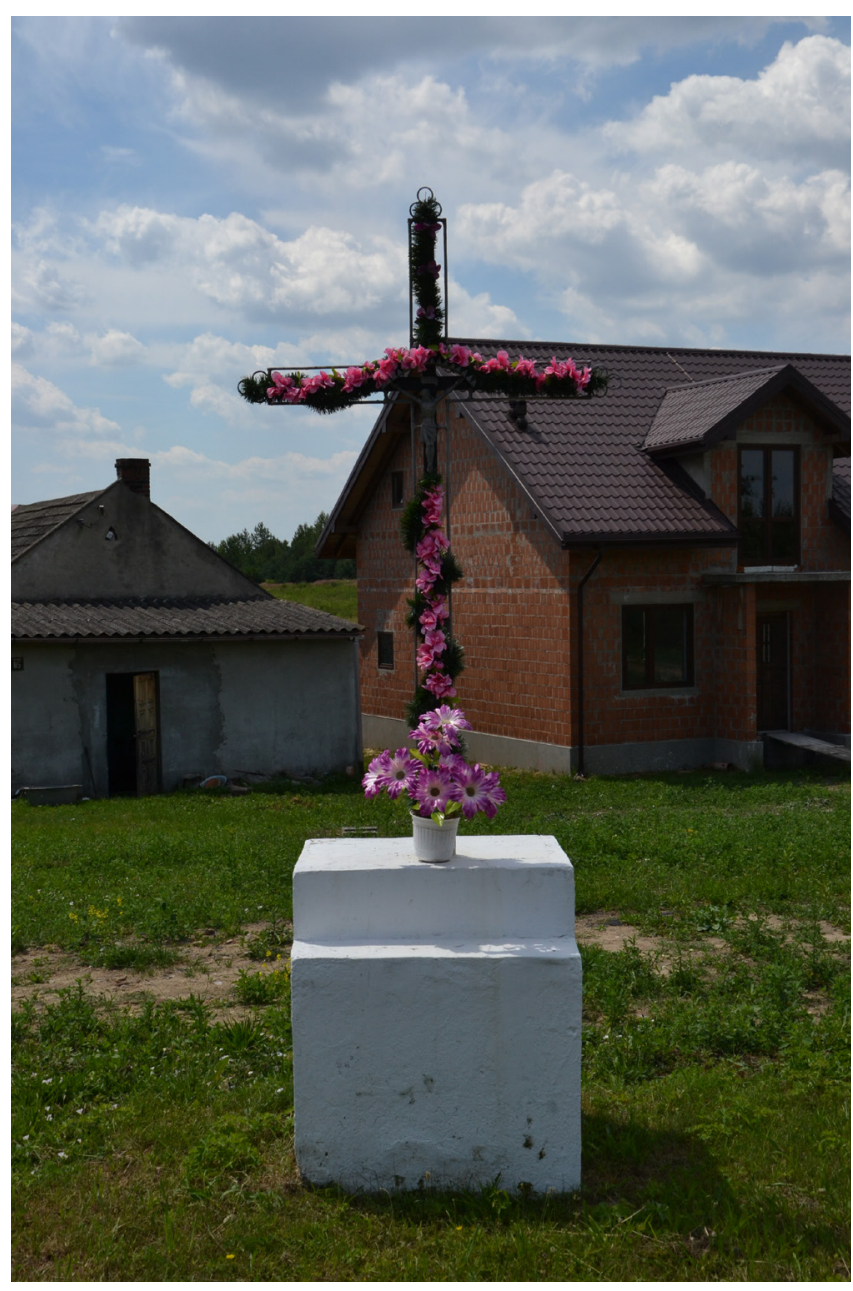

Fig. 15. Lusławice, a cross at the supposed choleric cemetery. A view from the north; photograph by M. Majorek; July 2016.

Wancerzów) is called by local inhabitants 'chaleric' (pol. chaleryczny), which they believe refers to the original purpose of the necropolis connected with burials of cholera victims at the end of the $19^{\text {th }}$ century (Figs. 21-22). This may be confirmed by the time of its creation as it is dated to years before $1880,{ }^{45}$ meaning years when a cholera epidemic was spreading in the area, and by the fact that at that time the function of a parish church was served, at least from the beginning of the $19^{\text {th }}$ century, by the graveyard at St Adalbert's church (today a chapel) in Częstochowska Street in Mstów. According to archival sources, in the winter of 1918 this place was turned by German military authorities into a cemetery for German and Russian soldiers who had fallen in $1914 .{ }^{46}$ The military necropolis operated there until 1935, when the Polish authorities exhumed the remains and moved them to the cemetery in Ciecierzyn near Olsztyn. After the Second World War,

\footnotetext{
${ }^{45}$ Borowska-Antoniewicz 2013, 61.

${ }^{46}$ Cf. Borowska-Antoniewicz 2013, 61; Orman and Orman 2015, 682-685.
}

a single-family housing estate, coming under Mstów in administrative terms, was built in place of the former cemetery. While digging foundations, workers found bone remains left after the exhumations from the mid1930 s. ${ }^{47}$ It seems probable that a choleric cemetery had indeed been established there in the 1870s; however, it was temporary, as at the same time (or several years later) a choleric cemetery was created near Dobra Mountain, farther away from human settlements. It should be added that some local inhabitants linked the term 'chaleric' to the name of General Józef Haller. It cannot be excluded that the German military cemetery mentioned was also the place of burial of a few Polish soldiers who were stationed in the nearby Wancerzów estate in the summer of 1918 and even had their own military field hospital in Mstów. ${ }^{48}$

\section{Conclusions}

Places in the physical landscape of the northern part of the Polish Jurassic Highland identified by local inhabitants with choleric cemeteries can be only partially linked to the tragic effects of the $19^{\text {th }}$-century epidemics. The ethnoarchaeological research ${ }^{49}$ carried out did not lead to a discovery of places of burial of cholera victims other than those already known from official historical narratives, such as academic publications, maps, and travel guides. Of course, one can indicate the small scale of research into the issue both as part of the project described and with regard to the archaeological research methods applied. Although the results of the verification probing research only carried out in two places cannot be representative of the whole area studied, one can venture their interpretation.

It seems that choleric cemeteries, through their connections with the tragedy that still inspires terror a few generations later, became an inherent part of collective memory to such an extent that their remains in the surrounding landscape need to be continuously exemplified. On the other hand, their unspecific character, partially resulting from the original, temporary exclusion of choleric necropolises not only from the world of the

\footnotetext{
${ }^{47}$ Orman and Orman 2015, 683.

${ }^{48}$ Kubicki 2012, 86; Krupa-Ławrynowicz et al. 2019, 155-156.

${ }^{49}$ Ethnoarchaeology, similarly to experimental archaeology, helps to identify and understand the way buildings, tools, weapons, clothes, etc. were created and used. Mostly employed for studying distant eras, it does not provide full source-based knowledge but a repository of more or less useful analogies that - which should be emphasised - are not usually necessary in the case of research into the modern era. An element common to the activity of ethnologists and archaeologists exploring the contemporary past and the classically defined ethnoarchaeology is the use of ethnographic interviews as a research method; Prinke 1973; Kobyliński 2012, 721-731; Marciniak and Yalman 2013; González-Ruibal 2016; Ławrynowicz 2019c, 39.
} 


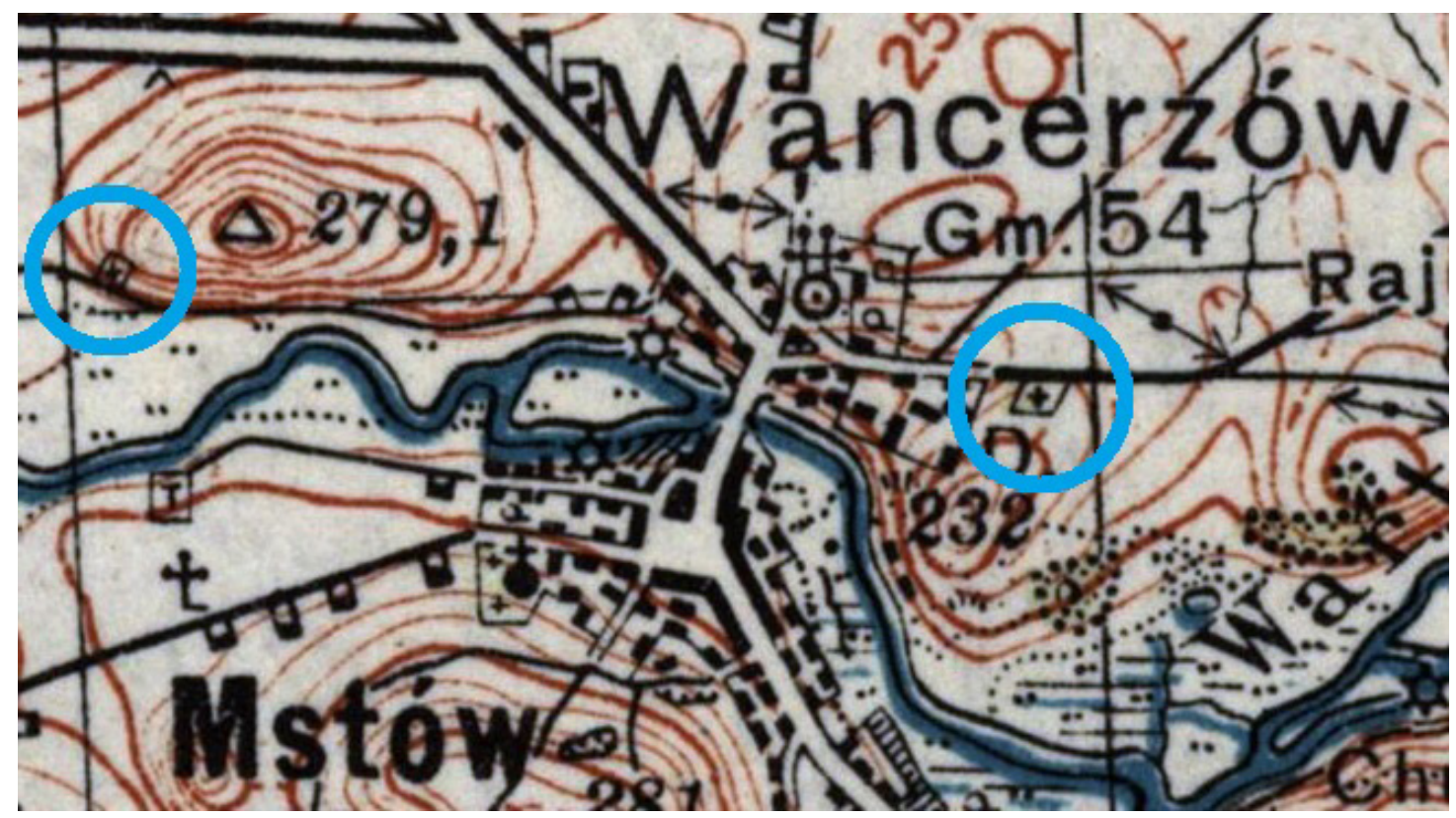

Fig. 16. Markings of the choleric cemetery on the slope of Dobra Mountain near Wancerzów (to the left) and the 'choleric cemetery' in Wancerzów (today in Mstów, to the right) on a fragment of a Polish tactical map of 1933.

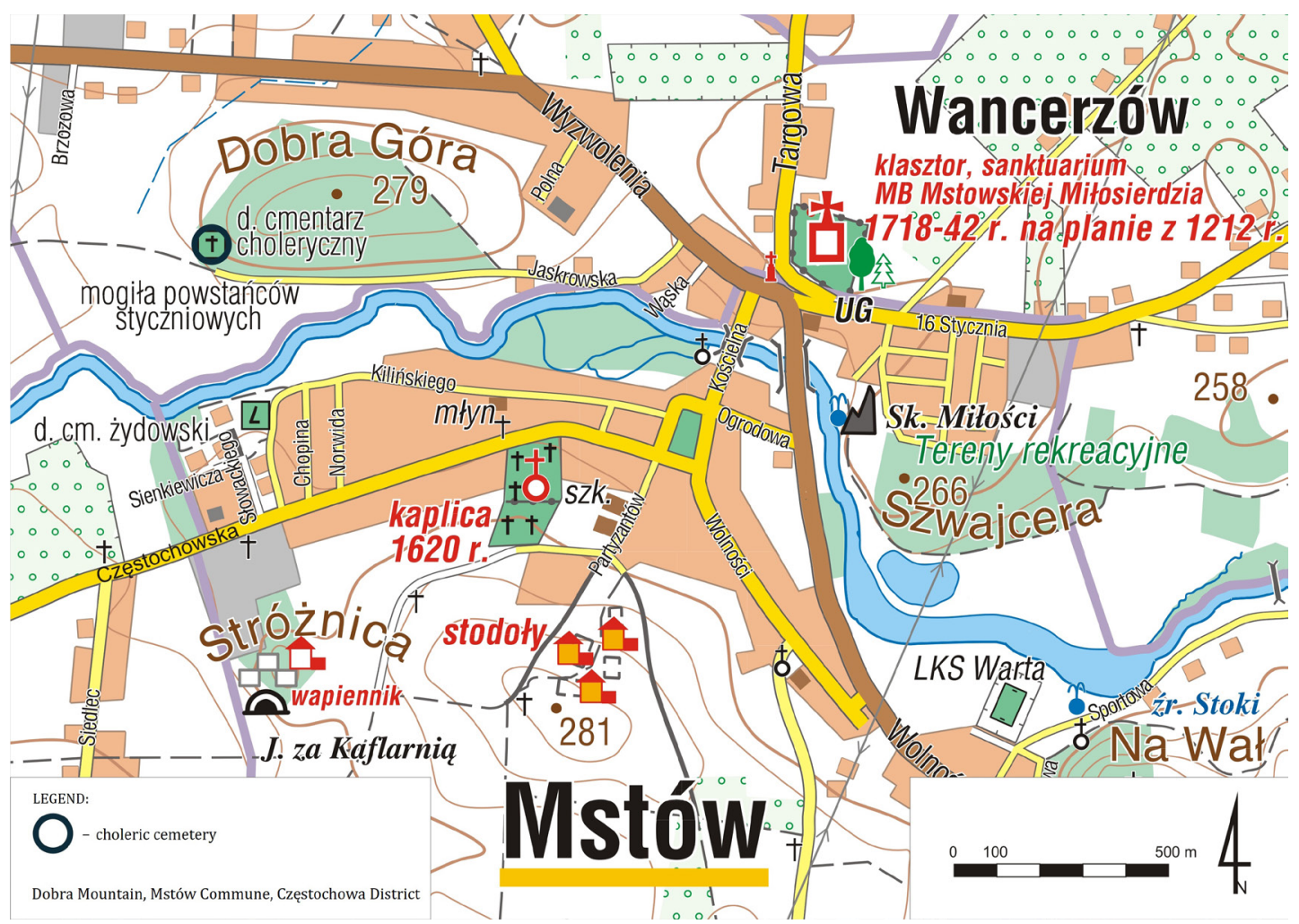

Fig. 17. Location of the choleric cemetery in Wancerzów (Mstów Commune) on a tourist map; prepared by W. Duda based on the map published by Wydawnictwo Kartogram Dariusz Faustmann. 




Fig. 18. Location of the choleric cemetery on the slope of Dobra Mountain in Wancerzów (Mstów Commune) on a LiDAR visualisation; prepared by A. Ginter, W. Duda based on the data of the Head Office of Geodesy and Cartography.
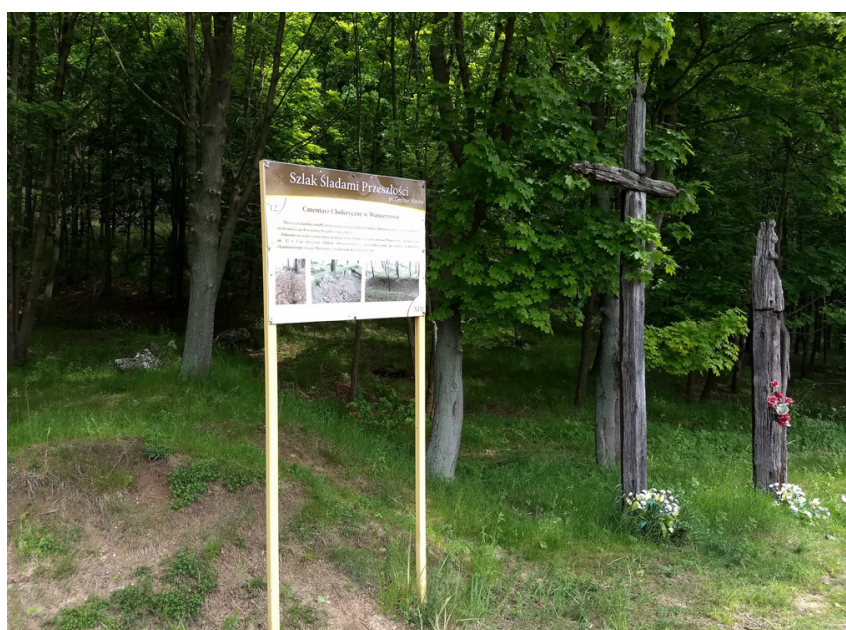

Fig. 19. Wancerzów, the 'Following the Past in the Mstów Commune' information board and the choleric cemetery on the slope of Dobra Mountain. A cross, as seen from the south-west; photograph by A. Krupa-Ławrynowicz, June 2020.

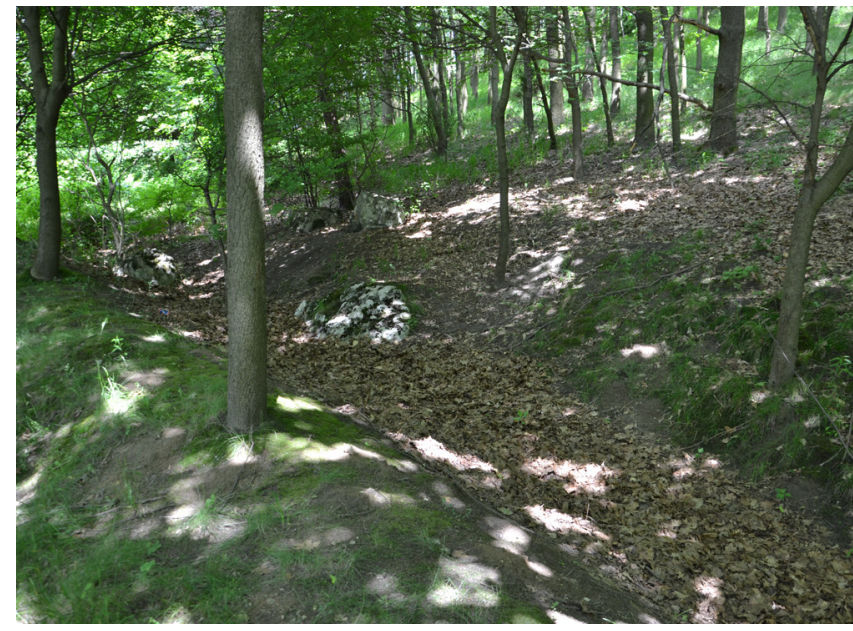

Fig. 20. Wancerzów, the choleric cemetery on the slope of Dobra Mountain. A view from the south; photograph by M. Majorek, June 2015. living but also from the world of the dead buried in regular cemeteries, made stories about the time of the epidemic and places of burial of its victims interesting to local communities for a long time. Even fragmentary knowledge of the ominous epidemic allowed people to determine functions of places that used to be marked with crosses. This unique discourse from the historical order was nothing unusual. Roadside crosses and mounds were also connected with distorted information about burials of January insurgents or the Second World War partisans. ${ }^{50}$ Stories about choleric cemeteries are so unspecific that they resemble accounts of mythological places collected during research in the Polish Jurassic Highland, concerning 'collapsed inns' ${ }^{51}$ (usually holes from which sand, clay, or limestone used to be excavated), tunnels connecting castles and monasteries (entries to caves and

\footnotetext{
${ }^{50}$ Ławrynowicz 2016b.

${ }^{51}$ Polish zapadłe karczmy.
} 


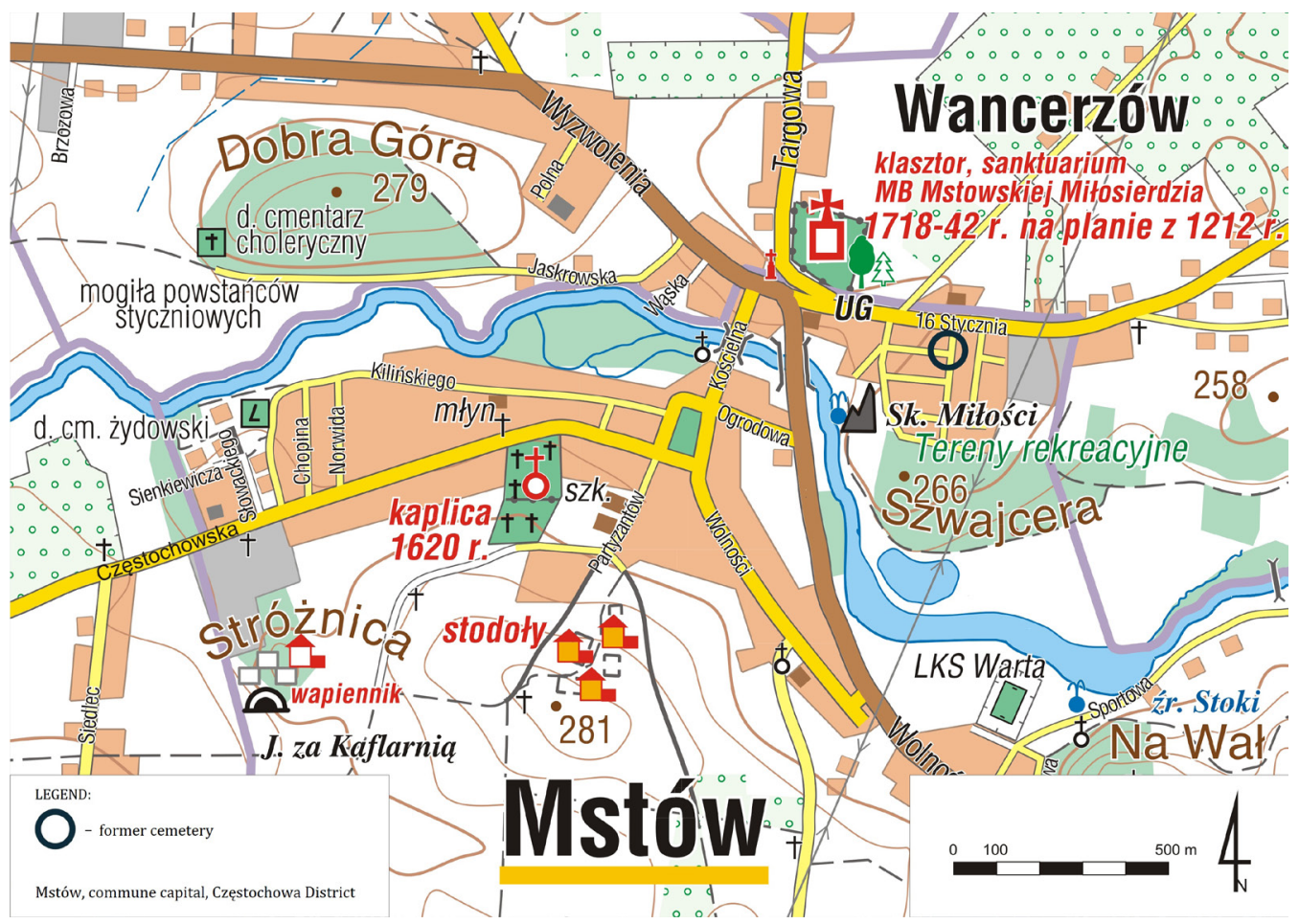

Fig. 21. Location of the supposed 'chaleric' cemetery in Mstów (commune capital) on a tourist map; prepared by W. Duda based on the map published by Wydawnictwo Kartogram Dariusz Faustmann.

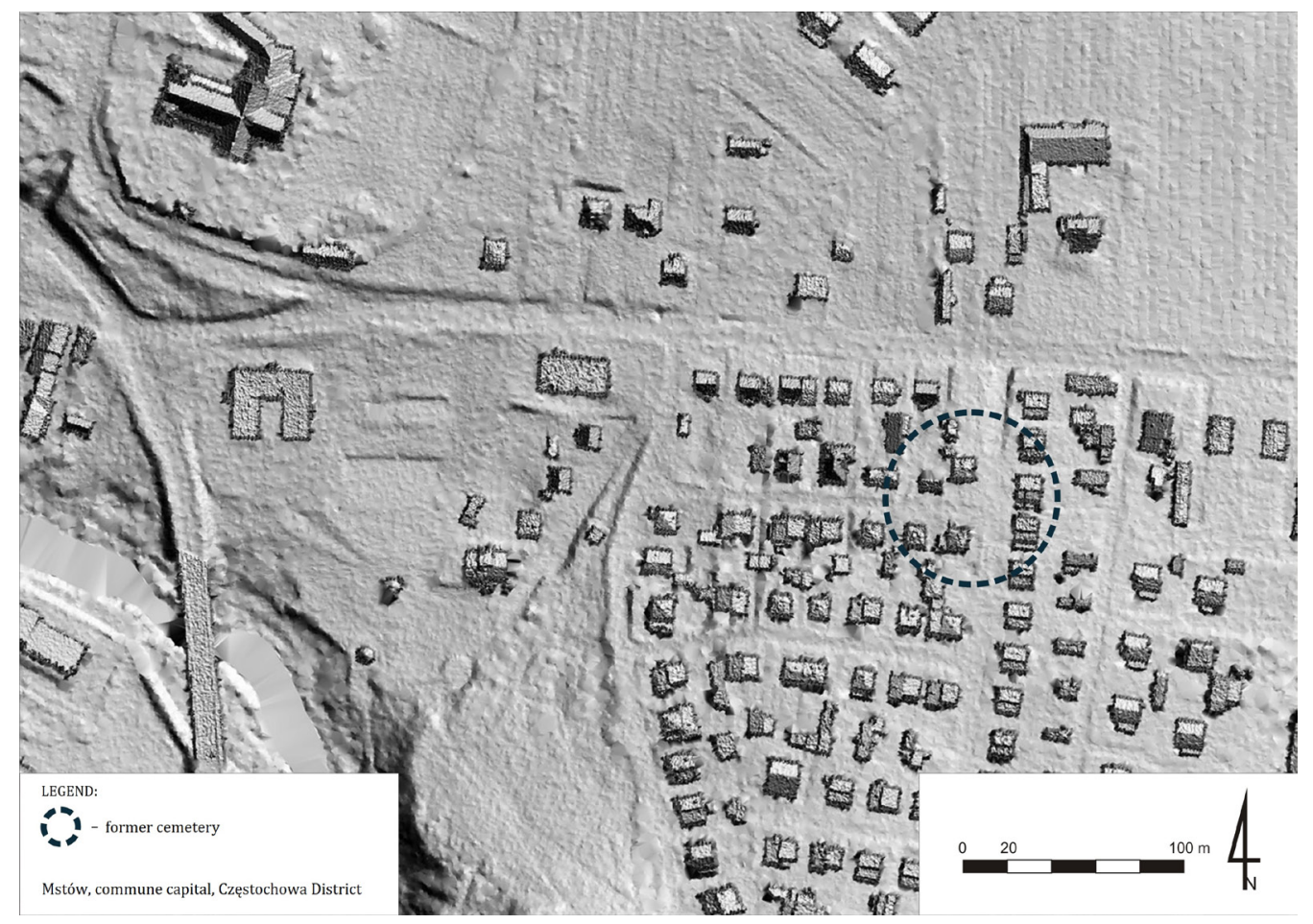

Fig. 22. Location of the supposed 'chaleric' cemetery in Mstów (commune capital) on a LiDAR visualisation; prepared by A. Ginter, W. Duda based on the data of the Head Office of Geodesy and Cartography. 
basements), and places where treasures were buried (under old trees, near shrines, etc.). ${ }^{52}$

The results of ethnoarchaeological research into places called choleric cemeteries presented in this paper should encourage researchers to investigate the issue of location of such places not only in the Polish Jurassic Highland in a more comprehensive and interdisciplinary way. Despite the expressed scepticism towards the 'reliability' of oral accounts concerning the supposed location of burial places of victims of the $19^{\text {th }}$-century cholera epidemics, some of the places identified during the research should be explored. This is required not only on account of the wish to respond to research challenges and expectations, but also on account of the humanitarian motivation to mark and commemorate epidemic victims, which is also very relevant today.

\section{References}

AACz 1853-1905. Archiwum Archidiecezji Częstochowskiej. Akta zmarłych, sygn. KM 1410.

Borowska-Antoniewicz J. 2013. Gminny program opieki nad zabytkami gminy Mstów 1. Zarys historii gminy Mstów. Mstów.

Czapliński M. P. 2012. Epidemie cholery w Rejencji Opolskiej w latach 1831-1894. Rybnik.

González-Ruibal A. 2014. Archaeology of the Contemporary Past. In: C. Smith (ed.), Encyclopedia of Global Archaeology. New York, 1683-1694.

González-Ruibal A. 2016. Ethnoarchaeology or simply archaeology? "World Archaeology” 48(5), 687-692.

Goździk P. W. 1939. Cholera w Królestwie Polskim w 1831 r. Warszawa.

Hirsch M. 1997. Family Frames. Photography, Narrative, and Postmemory. Cambridge, Massachusetts and London, England: Harvard University Press.

Karpińska G. E. 2016. Diagnoza badawcza gminy - etnografia. In: G. E. Karpińska, M. Majorek (eds.), Miejsca pamięci i miejsca zapomnienia. Interdyscyplinarne badania na Jurze Krakowsko-Częstochowskiej. Raport z badań 4: Gmina Janów. Łódź, 33-69.

Karpińska G. E., Majorek M, Janik M., Gadowska I. 2016. Diagnoza miejsc. In: G. E. Karpińska, M. Majorek (eds.), Miejsca pamięci i miejsca zapomnienia. Interdyscyplinarne badania na Jurze Krakowsko-Częstochowskiej. Raport z badań 4. Gmina Janów. Łódź, 109-274.

Karte... 1886. Karte des Deutschen Reiches, Berlin: Kartographie Abteilung der Königlich Preußisch Landes-Aufnahme. David Rumsey Map Collection; http://igrek.amzp.p1/details.php?id=17200. Available online: 10.07.2021.

Kobyliński Z. 2012. Etnoarcheologia. In: S. Tabaczyński, A. Marciniak, D. Cyngot, A. Zalewska (eds.), Przeszłość spoleczna. Próba konceptualizacji. Poznań, 721-731.

Kolbuszewski J. 1985. Wiersze z cmentarza. O współczesnej epigrafice wierszowanej. Wrocław.

Kulesza J. 1838. Opisanie cholery azjatyckiej jaka epidemicznie grasowała w Warszawie i Królestwie Polskiem w latach 1831, 1836 i 1837. Warszawa.

“Kurier Warszawski” 1873. "Kurier Warszawski”, nr 201.

Krupa-Ławrynowicz A. 2019. Diagnoza badawcza gminy - etnografia. In: A. Krupa-Ławrynowicz, O. Ławrynowicz (eds.), Miejsca pamięci i miejsca zapomnienia. Interdyscyplinarne badania na Jurze Krakowsko-Częstochowskiej. Raport z badań 2: Gmina Mstów. Łódź, 37-72.

Krupa-Ławrynowicz A. 2020. Lokalność w krajobrazie. Etnograficzny przypis do projektu "Śladami Przeszłości po Gminie Mstów”. "Zeszyty Wiejskie” 26, 221-242.

Krupa-Ławrynowicz A., Ławrynowicz O. 2016. O projekcie. In: A. P. Wejland, O. Ławrynowicz (eds.), Miejsca pamięci i miejsca zapomnienia. Interdyscyplinarne badania na Jurze Krakowsko-Częstochowskiej. Raport z badań 1: Wprowadzenie metodologiczne. Łódź, 8-18.

Krupa-Ławrynowicz A., Ławrynowicz O. 2019a. Etnoarcheologia w praktyce. Z badań niedawnej przeszłości. "Archaeologia Historica Polona" 27, 301-320.

Krupa-Ławrynowicz A., Ławrynowicz O. 2019b. Etnografia $i$ archeologia - perspektywa integrujaca / Ethnography and Archaeology - an Integrating Perspective. In: O. Ławrynowicz, A. Krupa-Ławrynowicz (eds.),

${ }^{52}$ Cf. Wejland 2016a, 45-46; Wejland 2019, 25-28. 
Miejsca pamięci i miejsca zapomnienia w krajobrazach kulturowych Jury Krakowsko-Częstochowskiej. Nawiazania i poszerzenia / Places of Memory and Oblivion in the Cultural Landscapes of the Polish Jurassic Highland. References and Extensions. Łódź, 55-72.

Krupa-Ławrynowicz A., Ławrynowicz O., Rak M., Nita M., Gadowska I. 2019. Diagnoza miejsc. In: A. Krupa-Ławrynowicz, O. Ławrynowicz (eds.), Miejsca pamięci i miejsca zapomnienia. Interdyscyplinarne badania na Jurze Krakowsko-Częstochowskiej. Raport z badań 2: Gmina Mstów. Łódź, 105-210.

Kubicki A. 2012. Z przeszłości Mstowa. Notatki kronikarskie od średniowiecza do 1939 roku. Częstochowa.

Ławrynowicz O. 2016a. Metodyka diagnozy archeologicznej. In: A. P. Wejland, O. Ławrynowicz (eds.), Miejsca pamięci i miejsca zapomnienia. Interdyscyplinarne badania na Jurze Krakowsko-Częstochowskiej. Raport z badań 1: Wprowadzenie metodologiczne. Łódź, 90-107.

Ławrynowicz O. 2016b. Góra Skarzawa. Archeologiczne (i nie tylko) odkrywanie miejsca. "Zeszyty Wiejskie” 22, 815-828.

Ławrynowicz O. 2019a. Diagnoza badawcza gminy - archeologia. In: A. Krupa-Ławrynowicz, O. Ławrynowicz (eds.), Miejsca pamięci i miejsca zapomnienia. Interdyscyplinarne badania na Jurze Krakowsko-Częstochowskiej. Raport z badań 2: Gmina Mstów. Łódź, 73-90.

Ławrynowicz O. 2019b. Archaeology of Us and the Local Identity. An Interdisciplinary Context. "Acta Universitatis Lodziensis. Folia Archaeologica" 34, 45-57.

Ławrynowicz O. 2019c. Jak bym to zrobit teraz. Aneks do procedury badań miejsc pamięci i miejsc zapomnienia / How I would do it now. An Appendix to the Procedure of Research into Places of Memory and Oblivion. In: O. Ławrynowicz, A. Krupa-Ławrynowicz (eds.), Miejsca pamięci i miejsca zapomnienia w krajobrazach kulturowych Jury Krakowsko-Częstochowskiej. Nawiazania i poszerzenia / Places of Memory and Oblivion in the Cultural Landscapes of the Polish Jurassic Highland. References and Extensions. Łódź, 37-54.

Majorek M. 2016. Diagnoza badawcza gminy - archeologia. In: G. E. Karpińska, M. Majorek (eds.), Miejsca pamięci i miejsca zapomnienia. Interdyscyplinarne badania na Jurze Krakowsko-Częstochowskiej. Raport z badań 4: Gmina Janów. Łódź, 70-86.

Mapa taktyczna ... 1933. Mapa taktyczna Polski, Warszawa: Wojskowy Instytut Geograficzny. Zbiory Archiwum Map WIG; http://igrek.amzp.pl/details.php?id=4561. Available online: 10.07.2021.

Marciniak A., Yalman N. 2013. Non-Anglophone Ethnoarchaeologies in the Past and Today: An Introduction. In: A. Marciniak, N. Yalman (eds.) Contesting Ethnoarchaeologies. Traditions, Theories, Prospects. New York, 1-13.

Matejak W., Pasternak A. 2010. Praski cmentarz choleryczny w Warszawie. Warszawa.

Mikołejko A. 2012. Miasto przeklęte, miasto święte. Zapis roku cholery. In: W. Pawluczuk, S. Zagórski (eds.), Miejsca święte, miejsca przeklęte. Polskie doświadczenie przestrzeni. Łomża, 117-131.

Novaya Topograficheskaya Karta ... 1912. Новая Топографическая Карта Западной России. Zbiory Wydziału Geografii i Studiów Regionalnych Uniwersytetu Warszawskiego; http://igrek.amzp.pl/details.php?id=1762751. Available online: 10.07.2021.

Orman K., Orman P. 2015. Wielka Wojna na Jurze. Dziatania i cmentarze wojenne z roku 1914 na Wyżnie Krakowsko-Wieluńskiej i terenach przyległych. Kraków.

O środkach zaradczych w epidemii cholery ... 1852. O środkach zaradczych w epidemii cholery w Królestwie Polskiem przedsiębranych, z dołaczeniem wiadomości lekarskich $i$ statystycznych. Warszawa.

Pigoń S. 1983. Z Komborni w świat. Wspomnienia młodości. Warszawa.

Prinke A. 1973. Możliwości porównawczego stosowania danych etnograficznych w archeologii. "Etnografia Polska" 17(1), 41-65.

Rumszewicz S. 1916. Cmentarz choleryczny na Zawodziu. "Goniec Częstochowski" 177, 4-6.

Surówka A. 2012. Cmentarz choleryczny w Lutoryżu (pow. rzeszowski). "Twórczość Ludowa” 2012(1/2), 18-19.

Sznajderman M. 2020. Zaraza. Mitologia dżumy, cholery i AIDS. Wołowiec.

Tomczyk R. 2015. Zagrożenia epidemiologiczne na terenie austriackiej części monarchii habsburskiej w XIX w. (do 1914 r.). Aspekty prawne i administracyjne. "Galicja. Studia i Materiały. Czasopismo Instytutu Historii Uniwersytetu Rzeszowskiego" 1, 99-113.

Udziela S. 1896. Cholera w pojęciach ludu ziemi sądeckiej. "Materiały Antropologiczno-Archeologiczne i Etnograficzne" 1, 1-4.

Wejland A. P. 2016a. Pojęcia podstawowe. In: A. P. Wejland, O. Lawrynowicz (eds.), Miejsca pamięci i miejsca zapomnienia. Interdyscyplinarne badania na Jurze Krakowsko-Częstochowskiej. Raport z badań 1: Wprowadzenie metodologiczne. Łódź, 38-49. 
Wejland A. P. 2016b. Strategia badawcza. In: A. P. Wejland, O. Ławrynowicz (eds.), Miejsca pamięci i miejsca zapomnienia. Interdyscyplinarne badania na Jurze Krakowsko-Częstochowskiej. Raport z badań 1: Wprowadzenie metodologiczne. Łódź, 50-58.

Wejland A. P. 2016c. Metodyka diagnozy etnograficznej. In: A. P. Wejland, O. Ławrynowicz (eds.), Miejsca pamięci i miejsca zapomnienia. Interdyscyplinarne badania na Jurze Krakowsko-Częstochowskiej. Raport z badań 1: Wprowadzenie metodologiczne. Łódź, 59-89.

Wejland A. P. 2019. Opowieści o miejscach-dopiski i komentarze / Narratives of Places. Notes and Comments. In: O. Ławrynowicz, A. Krupa-Ławrynowicz (eds.), Miejsca pamięci i miejsca zapomnienia w krajobrazach kulturowych Jury Krakowsko-Częstochowskiej. Nawiazania i poszerzenia / Places of Memory and Oblivion in the Cultural Landscapes of the Polish Jurassic Highland. References and Extensions. Łódź, 15-35.

Zalewska A. I. 2016. Archeologia czasów współczesnych w Polsce. Tu i teraz. In: A. I. Zalewska (ed.), Archeologia wspótczesności. Pierwszy Kongres Archeologii Polskiej 1. Warszawa, 21-39.

Związek J. 2004. 100 lat dziejów parafii Zajączki. http://niedziela.pl/artykul/25239/nd/100-lat-dziejowparafii-Zajaczki. Available online: 15.03.2020. 
